\title{
Application of Polyphenol-Loaded Nanoparticles in Food Industry
}

\author{
Danijel D. Milinčić ${ }^{1}$, Dušanka A. Popović ${ }^{1}$, Steva M. Lević ${ }^{1}$, Aleksandar Ž. Kostić ${ }^{1}$ (D, \\ Živoslav Lj. Tešić ${ }^{2}$, Viktor A. Nedović ${ }^{1}$ and Mirjana B. Pešić ${ }^{1, * \mathbb{D}}$ \\ 1 Department of Food Technology and Biochemistry, Faculty of Agriculture, University of Belgrade, \\ Nemanjina 6, 11080 Belgrade, Serbia; danijel.milincic@agrif.bg.ac.rs (D.D.M.); \\ dusanka.popovic@agrif.bg.ac.rs (D.A.P.); slevic@agrif.bg.ac.rs (S.M.L.); akostic@agrif.bg.ac.rs (A.Ž.K.); \\ vnedovic@agrif.bg.ac.rs (V.A.N.) \\ 2 Faculty of Chemistry, University of Belgrade, Studentski Trg, 12-16, 11158 Belgrade, Serbia; \\ ztesic@chem.bg.ac.rs \\ * Correspondence: mpesic@agrif.bg.ac.rs
}

Received: 27 September 2019; Accepted: 6 November 2019; Published: 16 November 2019

check for updates

\begin{abstract}
Nanotechnology is an emerging field of science, and nanotechnological concepts have been intensively studied for potential applications in the food industry. Nanoparticles (with dimensions ranging from one to several hundred nanometers) have specific characteristics and better functionality, thanks to their size and other physicochemical properties. Polyphenols are recognized as active compounds that have several putative beneficial properties, including antioxidant, antimicrobial, and anticancer activity. However, the use of polyphenols as functional food ingredients faces numerous challenges, such as their poor stability, solubility, and bioavailability. These difficulties could be solved relatively easily by the application of encapsulation. The objective of this review is to present the most recent accomplishments in the usage of polyphenol-loaded nanoparticles in food science. Nanoparticles loaded with polyphenols and their applications as active ingredients for improving physicochemical and functional properties of food, or as components of active packaging materials, were critically reviewed. Potential adverse effects of polyphenol-loaded nanomaterials are also discussed.
\end{abstract}

Keywords: nanotechnology; nanoparticles; nanomaterials; polyphenols; food processing; food packaging; nanofood; functional food

\section{Introduction}

Nanotechnology found a wide range of applications in the food sector [1,2], which includes food safety and quality, the targeted delivery of important compounds and increased bioavailability, the development of new products, the control of technological processes, packaging, and sensory improvements, such as texture and taste modifications [3-5] (Figure 1).

Nanodrugs and nanopharmaceuticals were developed first, but the applications of nanotechnology in food production and agriculture are rapidly increasing [6]; both food industry and consumers, as well as developing and developed countries, may benefit from them [7]. One of the main roles of nanotechnology in the food sector is the effective transport of important substances that have nutritional and generally beneficial effects to humans [8,9].

A novel approach in nanotechnology is green nanotechnology, which encourages environmental sustainability and green routes of synthesizing nanomaterials and minimizes costs and potential environmental risks. This approach emphasizes the usage of ecofriendly and biocompatible processes, usually with plant extracts or micro-organisms as active compounds or carriers [10,11]. Green 
nanotechnology is aimed toward the solution of modern problems and topics such as renewable energy, waste management, environmental remediation, and replacing hazardous processes and constituents [12]. The food sector could have huge benefits from adopting green nanotechnology, especially in those processes that are less energy-efficient or actively damage food compounds.

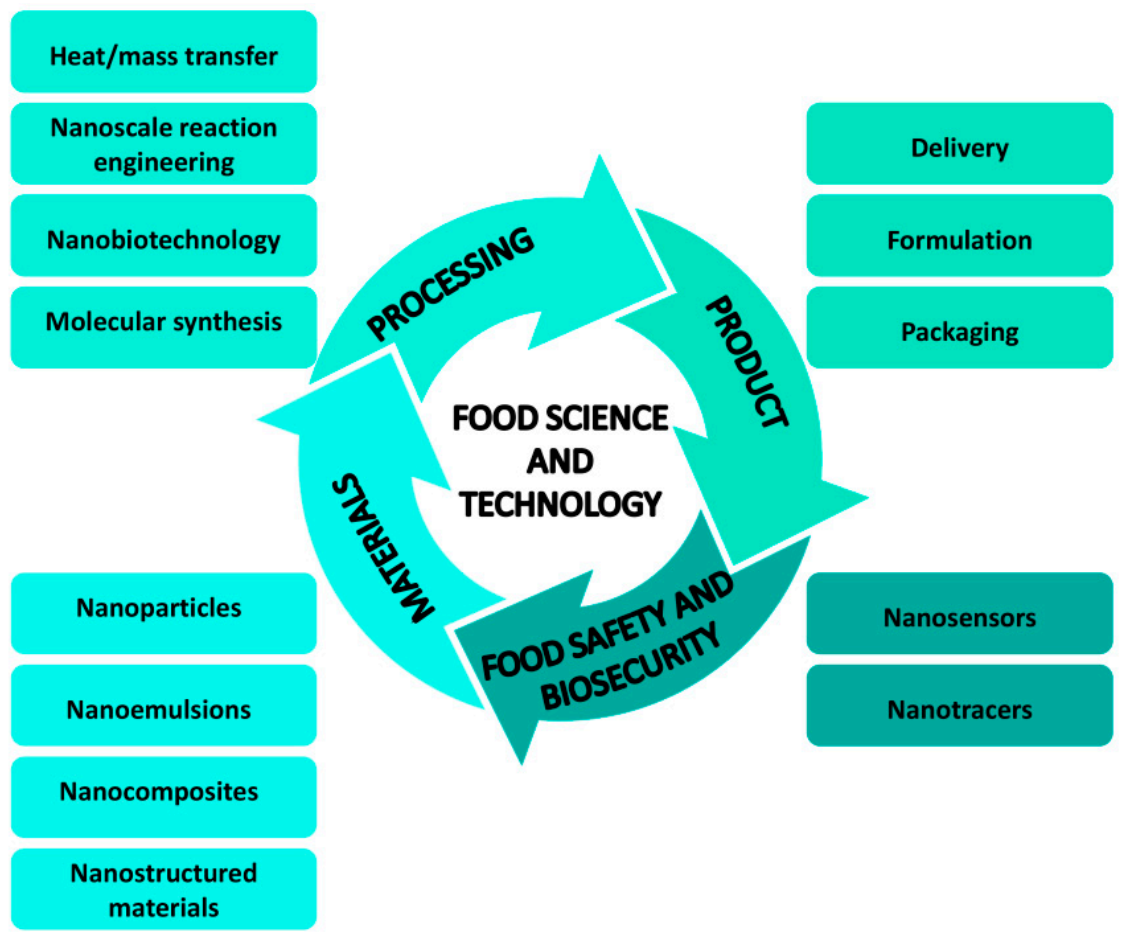

Figure 1. Schematic view of use of nanomaterials in food science and technology (adapted from Ramachandraiah et al. [13], with permission from publisher Asian-Australasian Journal of Animal Science, 2015).

The latest nanotechnology applications in food science include the development of functional foods and nanosized food compounds, the formation of delivery systems for bioactive compounds, and innovations in food packaging [14-17]. Both microencapsulation and nanoencapsulation aim to improve the functional properties of bioactive compounds or to effectively transport them to the target destinations [2].

There are numerous biologically active compounds that can be encapsulated, but for the food sector, the encapsulation of polyphenols is particularly important [2].

Polyphenols are widely studied secondary plant metabolites due to their potential positive effects on human metabolic processes [18-29]. Phenolic compounds have significant antioxidant and antimicrobial characteristics, but they are very unstable and susceptible to degradation processes, poorly soluble, and, in most cases, their bioavailability is relatively low [2]. So, incorporation of plants' phenolic compounds in food can significantly affect their physicochemical properties, stability, solubility, and bioavailability [1,30]. Encapsulation can prevent the degradation of phenolic compounds due to its protective effects against the negative impact of light, oxygen, and $\mathrm{pH}$. Encapsulation can also prevent interaction between polyphenols and other food components [31]. Further, polyphenol-loaded nanoparticles can be used for the development of new types of functional food, of which the consumption can help prevent various diseases [32].

Different nanocarriers for phenolic components can be used as a protective barrier, and they can roughly be divided into polysaccharide- and protein-based delivery systems [33]. Substances such as cyclodextrins, polymeric nanoparticles, nanomicelles [2], gelatin nanoparticles and films [34-36], food-protein nanoparticles like casein, whey proteins, soybean proteins [37,38], zein nanoparticles [39], chitosan [34,40], lipid nanocarriers [41,42], or protein-polysaccharide complex nanoparticles [43] have 
proven to be suitable carriers for the nanoencapsulation of polyphenolic compounds. The choice of carrier material affects the physicochemical characteristics of the encapsulated substances [44]. Food-protein nanoparticles and chitosan are the most commonly used nanocarriers for the delivery of plant polyphenols because there is solid evidence that they improve the intestinal absorption of phenolic compounds [34]. However, use of chitosan may be limited in the food industry because it has low solubility at neutral $\mathrm{pH}$ conditions and low delivery efficiency for individual components [45].

Recently, polysaccharide-protein nanocarriers have been reported as being promising for polyphenols encapsulation [46-48]. Active components bind to the protein part of the nanocarrier via hydrogen bonding and hydrophobic interactions, while polysaccharides contribute to the prevention of enzymatic protein degradation in gastric conditions [49]. Polysaccharide-bioactive peptide nanoparticles can also be valuable nanocarriers for the encapsulation of small molecular polyphenols, providing better bioavailability of these valuable components [50].

Among polyphenols, the most commonly encapsulated are catechins, quercetin, eugenol, epigallocatechin, epigallocatechin-gallate (EGCG), curcumin, and polyphenols derived from teas or essential oils (Table 1 ).

Table 1. Nanoencapsulation of phenolics important for food processing.

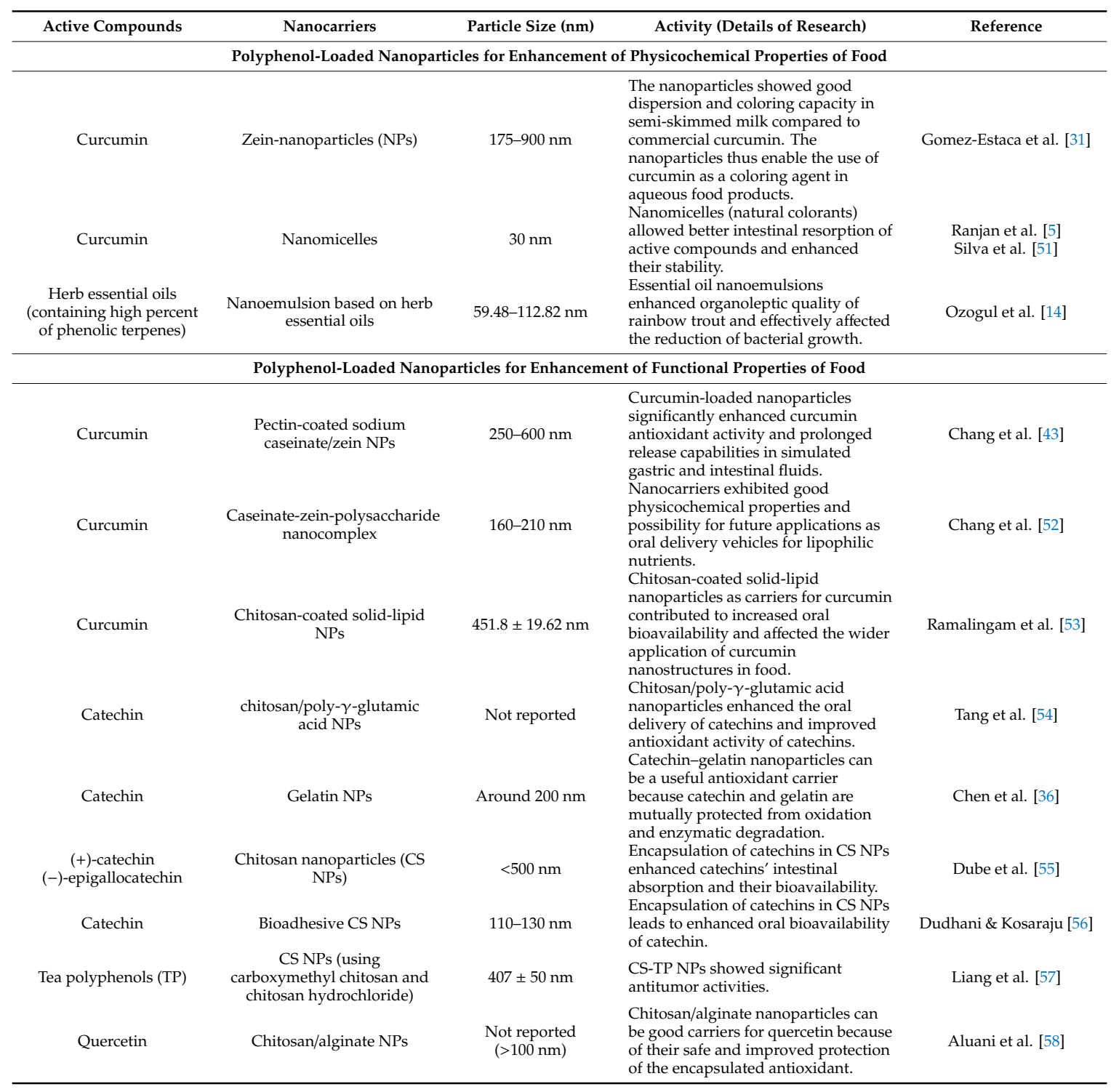


Table 1. Cont.

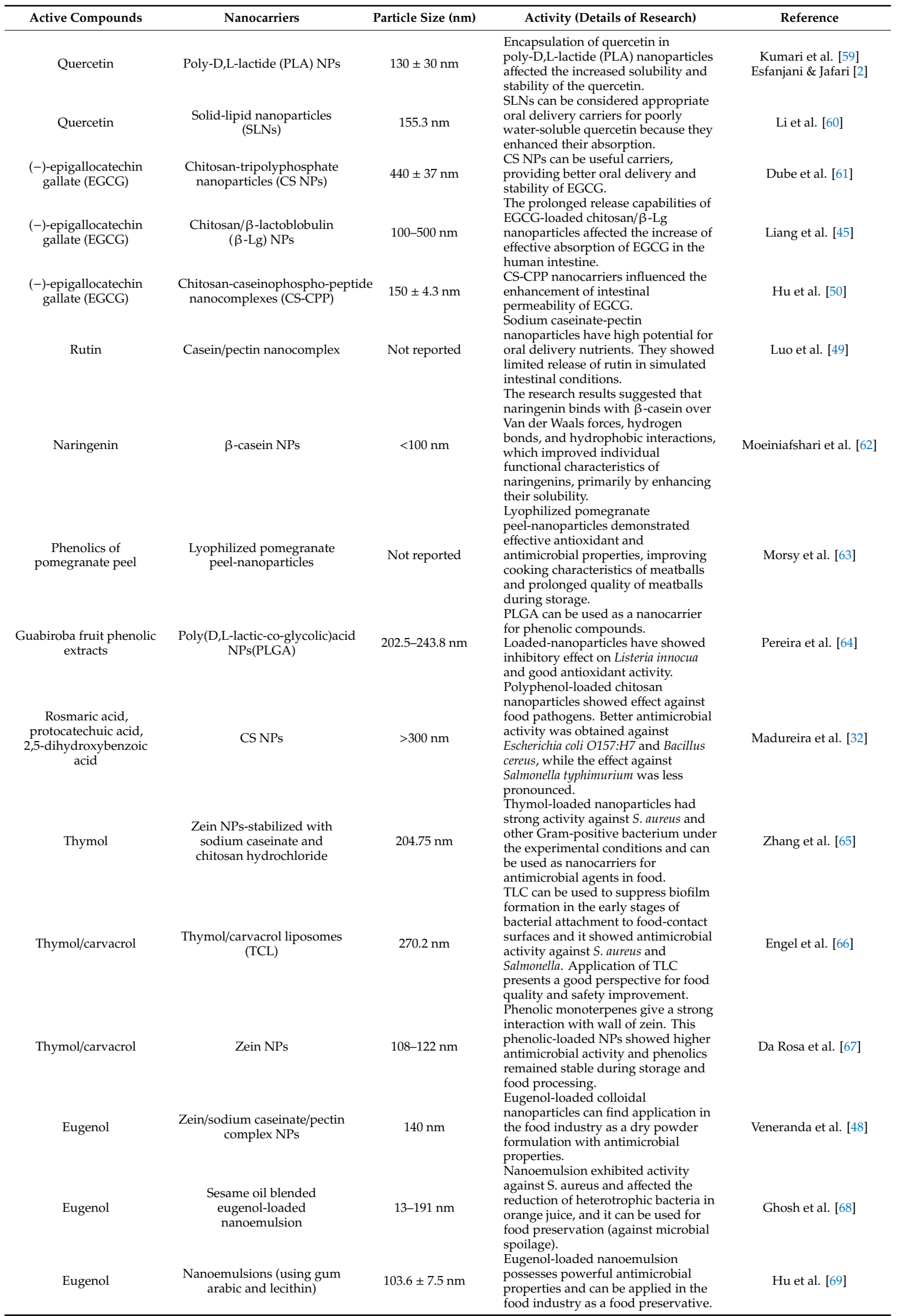


Table 1. Cont.

\begin{tabular}{|c|c|c|c|c|}
\hline Active Compounds & Nanocarriers & Particle Size (nm) & Activity (Details of Research) & Reference \\
\hline EGCG & $\begin{array}{l}\text { Nanostructured lipid carriers } \\
\text { (NLC) functionalized with } \\
\text { folic acid }\end{array}$ & $234-359 \mathrm{~nm}$ & $\begin{array}{l}\text { The developed formulation of } \\
\text { nanoencapsulated EGCG was } \\
\text { suitable for the oral delivery and has } \\
\text { potential for applications in the food } \\
\text { industry. }\end{array}$ & Granja et al. [70] \\
\hline $\begin{array}{l}\text { EGCG and EGCG + } \\
\text { piperine }\end{array}$ & Zein & 118.3 and $184.2 \mathrm{~nm}$ & $\begin{array}{l}\text { Optimization of nanoformulation of } \\
\text { EGCG alone and along with piperine } \\
\text { into a protein nanocarrier and the } \\
\text { study of their effect on in vitro } \\
\text { antioxidant, hemolytic, and } \\
\text { anticancer activities. }\end{array}$ & Dahiya et al. [71] \\
\hline $\begin{array}{c}\text { The fruit extract of Ribes } \\
\text { nigrum }\end{array}$ & $\begin{array}{l}\text { Silver nanoparticles } \\
\text { (Ag-NPs) }\end{array}$ & $5-10 \mathrm{~nm}$ & $\begin{array}{l}\text { Efficiency of nanoencapsulation, } \\
\text { characterization and bactericidal, } \\
\text { fungicidal, and anticancer activities } \\
\text { of nanoparticles synthesized using } \\
\text { the fruit extract of Ribes nigrum. }\end{array}$ & Dobrucka et al. [72] \\
\hline Curcumin and quercetin & $\begin{array}{c}\text { Re-assembled casein micelles } \\
(\mathrm{r}-\mathrm{CM}) \text { and casein } \\
\text { nanoparticles (CNPs) }\end{array}$ & $\begin{array}{c}186.9,66.2,72.8 \text {, and } \\
186.5 \mathrm{~nm}\end{array}$ & $\begin{array}{l}\text { Both CNP and r-CM significantly } \\
\text { improved the chemical stability of } \\
\text { phenolic compounds, and the } \\
\text { aqueous solubility was higher than } \\
\text { that of free molecules. }\end{array}$ & Ghayour et al. [73] \\
\hline $\begin{array}{c}\text { Orange oil } \\
\text { nanoemulsions }\end{array}$ & $\begin{array}{l}\text { Orange oil, carrier oil, } \\
\text { nonionic surfactant }\end{array}$ & $25-100 \mathrm{~nm}$ & $\begin{array}{l}\text { Orange oil as a lipophilic functional } \\
\text { agent was successfully incorporated } \\
\text { into nanoemulsions; the influence of } \\
\text { surfactant, oil composition, } \\
\text { temperature, and storage stability } \\
\text { were evaluated. }\end{array}$ & $\begin{array}{c}\text { Chang \& } \\
\text { McClements [75] }\end{array}$ \\
\hline $\begin{array}{c}\text { Thyme oil } \\
\text { nanoemulsions }\end{array}$ & $\begin{array}{l}\text { Thyme oil-in-water } \\
\text { nanoemulsions }\end{array}$ & 120 and $1300 \mathrm{~nm}$ & $\begin{array}{l}\text { Thyme oil was used as a core for } \\
\text { preparation of antimicrobial system } \\
\text { tested against acid-resistant spoilage } \\
\text { yeast, Zygosaccharomyces bailii. }\end{array}$ & Chang et al. [76] \\
\hline
\end{tabular}

Polyphenols can interact with nanocarriers. For example, it has been shown that there is a certain level of hydrogen bonding between catechin and unreacted amino groups of chitosan in their encapsulates [56]. Catechin can also interact with proline-rich proteins [2,77] or with the phenolic ring of EGCG with prolines in $\beta$-casein $[2,78]$. The mechanisms of encapsulation enabling polyphenol-nanocarrier interactions include ionic gelation, coacervation, liposome entrapment, inclusion complexation, co-crystallization, nanoencapsulation, freeze-drying, yeast encapsulation, and emulsion [79]. These various mechanisms can increase the bioavailability of polyphenols, prevent degradation in the gastrointestinal tract, enhance the delivery of polyphenols directly to the targeted sites [33], or provide stability during storage or processing [80].

The use of encapsulation technologies for the preparation and application of polyphenol-loaded microparticles in the food industry has recently been reviewed [81], but a similar review on polyphenol-loaded nanoparticles has not yet been published. Considering the significance of polyphenols and benefits from their nanoencapsulation, the aim of this paper is to give an overview of recent achievements in the application of polyphenol-loaded nanoparticles in food processing and packaging. The possible toxicity of nanomaterials is also discussed.

\section{Use of Polyphenol-Loaded Nanoparticles in Food Processing}

Polyphenol-rich nanoparticles can be used in food processing for the improvement of physicochemical characteristics, such as food stability, texture, and flavor profile, or functional properties such as antioxidant or antimicrobial activity (Table 1). Nanoencapsulation has become an important approach for preserving the properties of active components during food processing and consumption [82]. Further, nanotechnology-based sensor systems have been developed as alternatives for conventional analytical methods in safety and quality control [83].

\subsection{Polyphenol-Loaded Nanoparticles for the Enhancement of Physicochemical Properties of Food}

Encapsulation is a widely used technique for preserving different food properties [84]. The encapsulation of various substances provides solutions for numerous problems in the food sector, such 
as the improvement of organoleptic properties, by masking undesirable flavors, odors, and colors; control of volatility, solubility, stickiness, release of active compounds [85], and degradation; and the reduction of possible interactions with other food components, or with light and oxygen [31]. The first physical or chemical property to which consumers pay attention is color, and, because of its impact, it is an important characteristic for both science and industry.

Since polyphenols are a diverse group of plant metabolites, the encapsulation systems used for their protection might be different, too. Besides variations in chemical properties, the criteria for establishing appropriate encapsulation procedures also depend on required encapsulation properties (e.g., particle size, solubility, and controlled release).

Curcumin is a polyphenol present at the rhizomes of the Curcuma longa plant; generally, it serves as a distinct yellow-orange natural coloring for food [31] and has a strong impact on food flavor, but it is poorly soluble in water [31,52,86]. Its weak bioavailability and instability under neutral and alkaline $\mathrm{pH}$ conditions [31,87] limit its use in food. These problems can be solved by nanoencapsulation, and its potential use in food nanotechnology may bring novel functional foods with improved technological and sensorial properties. Nanoencapsulation could provide products with antioxidant and antimicrobial ingredients, or nanosized coloring agents and substances with improved water solubility [88]. Ranjan et al. [5] and Silva et al. [51] showed that, besides the use of nanomicelle-encapsulated curcumin for color improvement, these nanomicelles, at the same time, allow for its better intestinal bioavailability and enhanced stability (Table 1).

The use of native casein micelles (CM) as nanocarriers of biologically active compounds has recently gained attention. $\mathrm{CM}$ structure depends on the type of milk and can easily be modified by processing parameters [89-92], making CM an ideal platform for the delivery of bioactive compounds. It has been reported that $\beta$-carotene [93] and vitamin D [94] can be successfully loaded into native CM, enabling their improved storage stability and bioavailability. It was demonstrated that the addition of tea polyphenols to milk affects the technological properties of casein micelles: decreased gelling properties [95] and increased heat stability [96]. Knowing that milk is generally recognized as a source of beneficial substances for the growth and health of children and adults with the verified GRAS status of casein [97], it is worth trying to optimize the polyphenol nanoencapsulation process. Phenolic plant compounds could be extracted from byproducts of the food industry and further encapsulated in milk-based carriers, or other suitable protective materials using a spray-drying process. Spray drying is a commonly used method for the production of large quantities of encapsulates for the food industry. Besides the usage of elevated temperatures, it was shown that spray-drying preserves the main antioxidant properties of plant phenolic compounds [44]. Combining conventional encapsulation methods, such as spray drying, with newly developed nanocarriers could lead to the development of a new generation of dairy products, providing additional benefits to human health.

\subsection{Polyphenol-Loaded Nanoparticles for the Enhancement of Functional Properties of Food}

\subsubsection{Antioxidant Properties}

The aim of polyphenolic-nutrient nanoencapsulation is to protect and transport these active components and ensure their maximum bioavailability. For example, the dominant polyphenols of tea catechin and its derivatives (-)-epigallocatechin-3-gallate, (-)-epicatechin-3-gallate, (-)-epigallocatechin, and (-)-epicatechin, have strong biological properties, such as antioxidant and anticancer activities [36,45,98]; on the other hand, if they are not encapsulated, their bioavailability is low [98]. Consequently, there is a necessity for the development of effective delivery systems for improving of polyphenolic components' bioavailability.

In the study of Tang et al. [54], chitosan/ $\gamma$-PGA (PGA-edible polypeptide (poly- $\gamma$-glutamic acid)) nanoparticles were prepared for the oral delivery of tea catechins. Briefly, tea-catechin-loaded nanoparticles showed very effective radical scavenging capacity and could serve as suitable carriers for 
the transmucosal delivery of tea catechins. According to the same authors, nanoencapsulated catechins could be used as food additives and dietary supplements.

It has been found that, among tea polyphenols, EGCG has the largest scavenging capacity $[99,100]$, but in many studies, it has been indicated that EGCG has low bioavailability because of its large-sized molecules and the number of hydrogen bonds [100,101]. Application of chitosan/ $\beta$-lactoglobulin nanocarriers provided sustained release of tea EGCG and thereby increased its absorption in the human intestine [45]. Nanocarriers such as dextran sulfate, combined with N,N-dimethylhexadecyl carboxymethyl chitosan nanoliposome (DS-DCMC-NL), are also a suitable carrier for EGCG, which possesses a high encapsulation capacity and the potential for further application in food processing [102].

In addition to tea-polyphenol-loaded nanoparticles, there are studies that examined the nanoencapsulation of other polyphenol nutrients that exert antioxidant activity, such as curcumin $[5,43,51,52]$, quercetin [58-60], rutin [49], and naringenin [2,62]. According to Chang et al. [52], the use of pectin-coated $\mathrm{NaCas} /$ zein nanocarriers for curcumin encapsulation significantly improved its antioxidant activity and prolonged its release capabilities in simulated gastric and intestinal fluids, whereas quercetin-loaded solid-lipid nanoparticles improved its bioavailability [60]. The determination of the antioxidant properties of polyphenol-loaded nanoparticles was done using different antioxidant assays, such as ABTS/DPPH radical scavenging activity, hypochlorous acid/hydrogen peroxide scavenging assays, and ferric-reducing ability (Table 2).

Table 2. Methods used for determination of the biological properties of polyphenol-loaded nanoparticles.

\begin{tabular}{|c|c|c|c|}
\hline $\begin{array}{c}\text { Antioxidant/Cytotoxic } \\
\text { (Cell line/Animal Model) Assays }\end{array}$ & Active Compounds & Nanocarrier & Reference \\
\hline \multirow{4}{*}{ ABTS radical scavenging activity } & Curcumin & $\begin{array}{l}\text { Pectin-coated sodium caseinate/zein } \\
\text { NPs }\end{array}$ & Chang et al. [52] \\
\hline & Tea polyphenols & $\begin{array}{c}\text { Lysozyme-carboxymethyl cellulose } \\
\text { nanogels }\end{array}$ & Liu et al. [103] \\
\hline & Catechin & Chitosan/poly- $\gamma$-glutamic acid NPs & Tang et al. [54] \\
\hline & Curcumin & $\begin{array}{l}\text { Caseinate-zein-polysaccharide } \\
\text { nanocomplex }\end{array}$ & Chang et al. [43] \\
\hline \multirow{6}{*}{ DPPH radical scavenging activity } & Resveratrol & $\begin{array}{l}\text { Chitosan-TPP (sodium } \\
\text { tripolyphosphate) NPs }\end{array}$ & Wu et al. [104] \\
\hline & Resveratrol/quercetin & $\begin{array}{l}\text { Chitosan NPs/polyethylene glycol } \\
\text { modified chitosan NPs }\end{array}$ & Natesan et al. [105] \\
\hline & Resveratrol & PLGA [poly(lactic-co-glycolic acid)] & Kumar et al. [106] \\
\hline & Resveratrol/quercetin & Liposome & Caddeo et al. [107] \\
\hline & Tea polyphenols & $\begin{array}{l}\text { Lysozyme-carboxymethyl cellulose } \\
\text { nanogels }\end{array}$ & Liu et al. [103] \\
\hline & Catechin & Chitosan/poly- $\gamma$-glutamic acid NPs & Tang et al. [54] \\
\hline Hypochlorous acid (HOCl) scavenging assay & Resveratrol & Bovine serum albumin-based NPs & Fonseca et al. [108] \\
\hline Ferric-reducing ability (FRP) & Resveratrol/quercetin & $\begin{array}{l}\text { Chitosan NPs/polyethylene glycol } \\
\text { modified chitosan NPs }\end{array}$ & Natesan et al. [105] \\
\hline Hydrogen peroxide scavenging assay & Resveratrol & $\begin{array}{l}\text { PLGA [poly(lactic-co-glycolic acid)] } \\
\text {-oil hybrid NPs }\end{array}$ & Kumar et al. [106] \\
\hline $\begin{array}{l}\text { TEER measurements and transport studies } \\
\text { (Caco- } 2 \text { cell) }\end{array}$ & Catechin & Chitosan/poly- $\gamma$-glutamic acid NPs & Tang et al. [54] \\
\hline $\begin{array}{l}\text { Cell viability (Hepatocellular carcinoma cells } \\
\text { SMMC7721 and hepatocyte LO2 cells) }\end{array}$ & Resveratrol & $\begin{array}{l}\text { Chitosan-TPP (sodium } \\
\text { tripolyphosphate) NPs }\end{array}$ & Wu et al. [104] \\
\hline $\begin{array}{l}\text { Monkey kidney (Vero) cell } \\
\text { lines-sulforhodamine B assay }\end{array}$ & Resveratrol & $\begin{array}{c}\text { PLGA [poly(lactic-co-glycolic acid)] } \\
\text {-oil hybrid NPs }\end{array}$ & Kumar et al. [106] \\
\hline $\begin{array}{l}\text { Antitumor effect in vitro assays (CT26 mouse } \\
\text { colon cancer cells) }\end{array}$ & Resveratrol & $\begin{array}{l}\text { Polyethylene glycol-polylactic acid } \\
\text { polymer NPs }\end{array}$ & Jung et al. [109] \\
\hline $\begin{array}{l}\text { In vitro cell culture study (Cochlear cell lines } \\
\text { (HEI-OC1 and SVK-1) }\end{array}$ & Resveratrol & Polymeric NPs & Musazzi et al. [110] \\
\hline $\begin{array}{l}\text { In vitro hemolytic/anticancer assay (human } \\
\text { cancer cell lines i.e., leukemia cancer (HL60), } \\
\text { oral cancer (SCC40), breast cancer (MCF7), } \\
\text { cervix cancer (HeLa) and colon cancer } \\
\text { (Colo205)- sulforhodamine B assay) }\end{array}$ & EGCG/EGCG + piperine & Zein & Dahiya et al. [71] \\
\hline $\begin{array}{l}\text { In vitro cytotoxicity assay (SK-MEL-28 and } \\
\text { Colo-38 cells) }\end{array}$ & Resveratrol & Ultradeformable liposomes & Cosco et al. [111] \\
\hline $\begin{array}{l}\text { In vitro assays in cells from different origin } \\
\text { (cultivated HepG2 cells, isolated primary rat } \\
\text { hepatocytes, isolated murine spleen } \\
\text { lymphocytes and macrophages) }\end{array}$ & Quercetin & Chitosan/alginate NPs & Aluani et al. [58] \\
\hline $\begin{array}{c}\text { In vitro cytotoxicity assay } \\
\text { (Human hepatoma HepG2 cells) }\end{array}$ & Tea polyphenols (TP) & $\begin{array}{l}\text { CS NPs (using carboxymethyl } \\
\text { chitosan and chitosan hydrochloride) }\end{array}$ & Liang et al. [57] \\
\hline $\begin{array}{l}\text { In vitro assay (human hepatoblastoma cancer } \\
\text { cell line HepG2) }\end{array}$ & Tea polyphenols & $\begin{array}{l}\text { Lysozyme-carboxymethyl } \\
\text { cellulose nanogels }\end{array}$ & Liu et al. [103] \\
\hline
\end{tabular}


Table 2. Cont.

\begin{tabular}{|c|c|c|c|}
\hline $\begin{array}{c}\text { Antioxidant/Cytotoxic } \\
\text { (Cell line/Animal Model) Assays }\end{array}$ & Active Compounds & Nanocarrier & Reference \\
\hline $\begin{array}{l}\text { Evaluation of cell proliferative activity } \\
\text { (nonmalignant line of fibroblasts } \\
\text { CCD-39Lu-isolated from lungs and adherent } \\
\text { epithelial non-small cell lung cancer } \\
\text { cell line A549) }\end{array}$ & $\begin{array}{c}\text { The fruit extract of Ribes } \\
\text { nigrum }\end{array}$ & Silver nanoparticles (Ag-NPs) & Dobrucka et al. [72] \\
\hline In vitro assay (Human dermal fibroblasts) & Resveratrol/quercetin & Liposome & Caddeo et al. [107] \\
\hline $\begin{array}{l}\text { Antitumor effect in vivo assays } \\
\text { (CT26 mouse colon cancer cells) }\end{array}$ & Resveratrol & $\begin{array}{c}\text { Polyethylene glycol-polylactic acid } \\
\text { polymer NPs }\end{array}$ & Jung et al. [109] \\
\hline $\begin{array}{l}\text { IOP reducing efficiency } \\
\text { (normotensive rabbits) }\end{array}$ & Resveratrol/quercetin & $\begin{array}{l}\text { Chitosan NPs/polyethylene glycol } \\
\text { modified chitosan NPs }\end{array}$ & Natesan et al. [105] \\
\hline $\begin{array}{c}\text { In vivo study of antidiabetic activities } \\
\text { (Wistar rats) }\end{array}$ & Curcumin & Chitosan CS-ZnO-NC NPs & Chauhan et al. [112] \\
\hline $\begin{array}{l}\text { In vivo toxicological evaluation } \\
\text { (Male Wistar albino rats) }\end{array}$ & Quercetin & Chitosan/alginate NPs & Aluani et al. [58] \\
\hline
\end{tabular}

Hydroxycinnamic acids (HAs; ferulic, caffeic, synaptic, and coumaric acid) were successfully incorporated into lipid-core nanocapsules that can be used for the production of functional foods. This delivery system was able to preserve HAs in simulated gastric fluids and to enable their release in the simulated intestinal fluid [113]. Simulated in vitro gastrointestinal digestions are a valuable tool for determining the bioaccessibility of polyphenols, and scientists researching the topic of polyphenol-based food nanocapsules must take into consideration the effect of polyphenol co-digestion with different food components and the complex interactions between polyphenols and a food matrix [30]. In the study of Pešić et al. [30], enrichment of meat- and cereal-based products with grape polyphenol extracts appeared to be beneficial, but a review by Silva et al. [114] outlined both advantages and limitations of nanoencapsulated polyphenols when added to dairy beverages, since interactions with the food matrix may alter the bioavailability of polyphenols and even devitalize their function.

\subsubsection{Antimicrobial Properties}

Frequent foodborne-disease outbreaks are one of the main concerns of the food industry. This is one of the reasons why consumer demands for the use of natural components have increased, which leads to the improvement of microbiological safety. Incorporation of components that possess antimicrobial activity into adequate nanocarriers can help control or prevent the growth of pathogens and spoilage micro-organisms [115]. It is assumed that polyphenols exhibit an antimicrobial effect because of their absorption to cell membranes and interaction with enzymes [32]. Eugenol belongs to the group of phenolic components that possess strong antimicrobial and antioxidant capacity [116], but it has low water solubility $[48,69]$, and its applications are limited. Stable eugenol-loaded zein/caseinate/pectin complex nanoparticles obtained through a heat- and $\mathrm{pH}$-induced complexation process could find application in the food industry as dry-powder formulation with antimicrobial properties [48]. In a study by Ghosh et al. [68], sesame-oil-blended eugenol-loaded nanoemulsion formation, as well as properties of obtained nanoemulsion, such as droplet size and stability, depended on the type of surfactant. This emphasizes the need for proper emulsion formation/stabilization using adequate emulsifiers. Nanoemulsion formed in this way exhibited pronounced activity against $S$. aureus and affected the reduction of heterotrophic bacteria in orange juice.

It has been shown that thymol acts on Gram-positive and -negative bacteria $[65,117]$ and has a strong impact on food flavor, but it is poorly soluble in water [65]. Thymol-loaded zein nanoparticles stabilized with sodium caseinate and chitosan hydrochloride obtained by liquid-liquid dispersion showed strong antimicrobial activity against $S$. aureus and could potentially be used as delivery systems for antimicrobial agents in food products [65]. In an earlier study performed by Hu et al. [98], thymol-loaded chitosan nanoparticles showed stronger activity against Gram-positive bacteria compared to Gram-negative bacteria.

Formation of a nanocomplex between chitosan and different phenolics, such as rosmaric acid, protocatechuic acid, and 2,5-dihydroxybenzoic acid, against food pathogens has been described by Madureira et al. [32]. Briefly, polyphenol-loaded chitosan nanoparticles had better antimicrobial 
activity against Escherichia coli O157:H7 and Bacillus cereus, while, against Salmonella Typhimurium, they had lesser activity. The obtained images by electronic microscopy showed mechanisms of bacterial-cell damage. After polyphenol adsorption, holes on the surface of the cell were noticed, and even lysis was possible. Other antimicrobial components in the nanoencapsulated forms could be even more efficient against pathogens. For example, natural antimicrobials from propolis showed better antimicrobial activity when they were in the form of nanosized particles [118].

\subsubsection{Health-Promoting Properties}

Besides antimicrobial properties, the potential health benefits of polyphenols were in a much broader scope of numerous studies in recent years. The beneficial effects of resveratrol, such as antioxidant, antitumor, anti-inflammatory, and antiaging effects, can be improved by nanoencapsulation [119]. However, among numerous investigations, only few in vivo studies were performed to confirm the health-promoting properties of nanoencapsulated resveratrol, indicating that further research is required [120]. Curcumin also showed antidiabetic properties when curcumin-metal ( $\mathrm{ZnO})$ complexes were loaded with chitosan [112]. The addition of curcumin nanocapsules in food also resulted in improved functional properties (better solubility and stability, and lower degradation rate) while keeping its remarkable biological functions [121]. The study of Di Costanzo and Angelico [122] reviewed the numerous possibilities of silymarin nanoencapsulation, a mixture of flavonolignan and flavonoid polyphenolic compounds from the Silybum marianum seed, which has significant biological potential (antioxidant, anti-inflammatory, anticancer, and antiviral activities).

The synergistic effect of polyphenols is being studied, and it is known that certain polyphenol combinations have better health-promoting characteristics when combined rather than with the sum of individual ones [123].

Nanogels where tea polyphenols were encapsulated with lysozyme and carboxymethyl cellulose showed antitumor effects and represent a promising carrier for functional food ingredients [103]. There are numerous studies pointing out the useful biological functions of green-tea polyphenols: anti-inflammatory, antiproliferative, antihypertensive, antithrombogenic, and lipid-lowering effects [100], emphasizing the role of epicatechin [124], catechin [125], and other polyphenols that may find their function in food nanotechnology. However, the majority of conducted investigations were to estimate the anticancer activity of polyphenol-loaded nanoparticles on different cancer cells, such as hepatocyte, kidney, colon, oral, breast, and cervix cells (Table 2).

Further, it should be emphasized that the beneficial effects of polyphenols were claimed in the literature mostly on the basis of in vitro studies, but were not demonstrated in in vivo studies. For example, a relationship has not been established between catechin consumption from green tea (Camellia sinensis (L.) Kuntze) and the maintenance of normal blood cholesterol concentrations, normal blood pressure, normal vision, normal bones, or the protection of DNA, proteins, or lipids from oxidative damage [126]. The same conclusion was reported for olive-oil polyphenols and the maintenance of normal blood HDL cholesterol concentrations [127], or for flavonoids from fruit juices and antioxidativity, and flavonoids from citrus and vascular health [128].

\section{Use of Polyphenol-Loaded Nanoparticles in Food Packaging}

Packaging is a very significant operation in the food industry. Nanotechnology plays an important role in research and innovation in packaging technology, such as smart and active packaging [129-131]. Nanoparticle incorporation into packaging materials improves their barriers (gas/water/aroma), mechanical or oxygen-scavenging properties, thus enhancing food quality and prolonging the shelf-life [82]. In addition to improving the physical properties of packaging materials, nanoparticles add other functions, such as antimicrobial and antioxidant properties, or act as nanosensors/nanobiotracers, enabling better food security [82,132].

There is a growing demand for the development of new environmentally friendly films for food packaging based on biomaterials [133]. Nanofilms compared to traditional food-packaging films 
should have another dimension: the slow and controlled release of antimicrobial and other active components [134]. This is especially important in the case of antioxidants that, as components of packaging materials may provide prolonged shelf-life for food products (Table 3). Nanoemulsions containing polyphenols have been used for creating fruit-based edible films, which showed not only good antimicrobial and physicomechanical properties (such as permeability to water vapor), but also had an environmentally friendly dimension thanks to waste usage from the food industry. Pectin/papaya puree/cinnamaldehyde nanoemulsion edible composite films could be environmentally friendly antimicrobial packaging material for food applications [133].

It has also been demonstrated that the antibacterial properties of nanoencapsulated cinnamaldehyde used for food coatings were better when compared with free cinnamaldehyde. These films showed significant activity against E. coli and B. cereus [134].

Besides coating, food shelf-life could be prolonged with protection against the oxidation of fatty foods, using polyphenols such as EGCG in the form of nanosized particles [135]. A similar effect was obtained with green-tea polyphenol-loaded nanoparticles for the same purpose [136]. The incorporation of sage extract (Salvia officinalis L.) to poly ( $\varepsilon$-caprolactone) films resulted in the formulation of potential food-packaging material with both antioxidative and antimicrobial functions [137].

\section{Nanomaterial and Polyphenol Toxicity}

Contrasted with the benefits of nanotechnology, the potential risks this application could bring should be considered. Although there is still no evidence on the health risks of polyphenol-loaded nanoparticles, the risk assessment of nanomaterials, such as nanosilver, zinc oxide, or silicon dioxide, used for their encapsulation, was conducted and well-reviewed [132]. On the other hand, the potential toxicities of polyphenols were also reported in the literature, along with their health benefits [138].

\subsection{Nanomaterial Toxicity}

The EU Commission Recommendation's definition of the term "nanomaterial" is based only on the size of the nanoparticle, without dealing with its potentially hazardous characteristics (2011/696/EU). Nanotoxicology deals with the adverse effects resulting from exposure to nanomaterials with hazard potential [139]. The key physicochemical properties of nanoparticles that are responsible for toxicity include particle size, surface area and reactivity, crystal structure, aggregation abilities, composition/surface coatings, synthesis and preparation modifications, and purity of sample [140]. Special concerns refer to the uses of engineered nanoparticles (ENPs) in food-packaging materials, such as nanosilver, silanated silicon dioxide, titanium dioxide, iron oxide, or zinc oxide, and their possible migration into foodstuff. The migration is influenced not only by the physicochemical properties of ENPs but also by environmental conditions, type of food, characteristics of packaging materials, position of the ENPs in the packaging materials and their interactions, and contact time, which were recently well-reviewed by Enescu et al. [132]. These authors also gave an overview of current regulations on active food and beverage packaging, standard methods, and analytical techniques to monitor the overall and specific migration of ENPs, as well as their potential health risks. 
Table 3. Nanoencapsulation of phenolics important for food packaging.

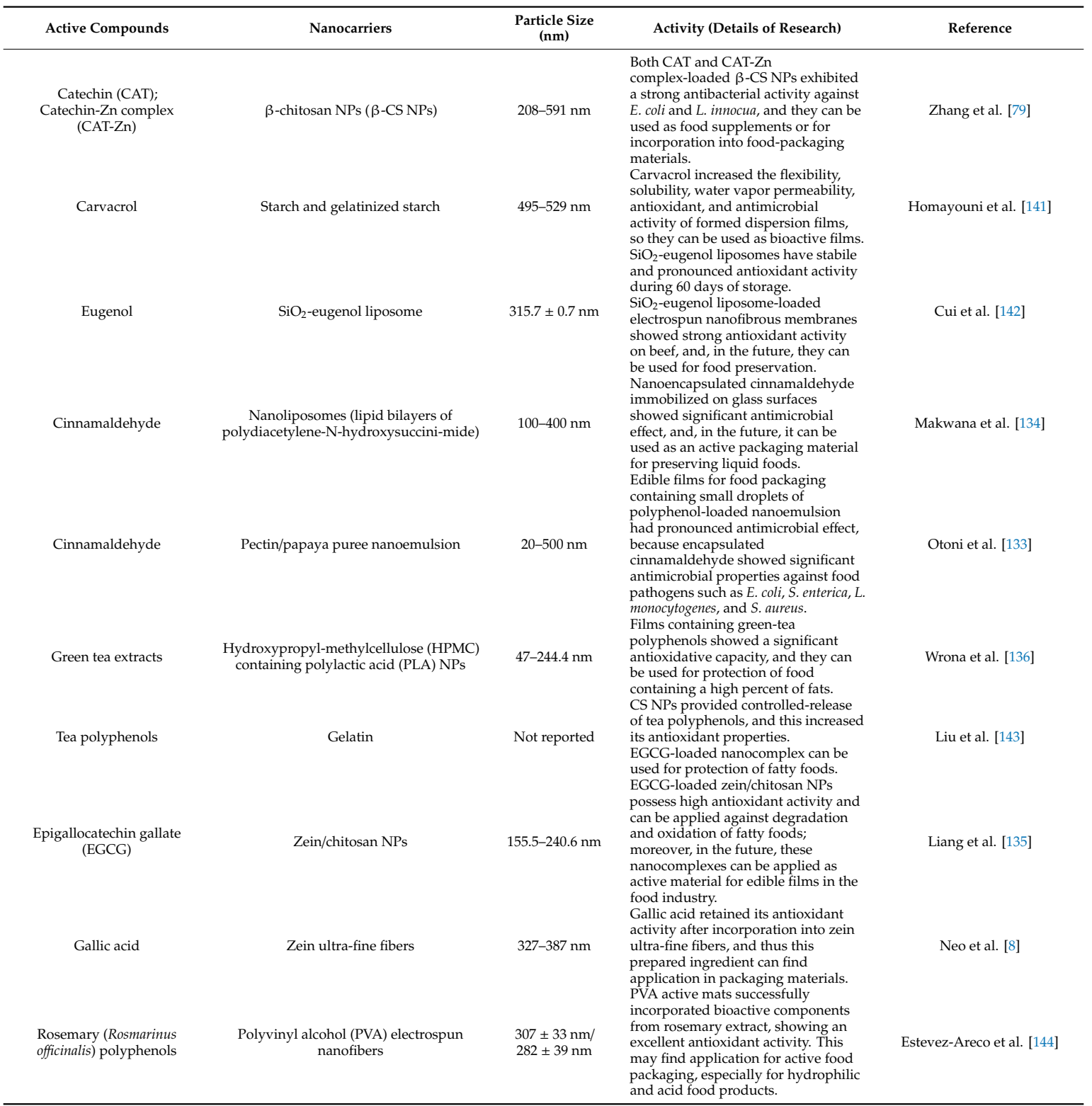

The physicochemical properties of these particles can create a pro-oxidant environment in cells, which leads to the creation of free radicals and inflammation or even cell death [145]. Different in vivo and in vitro studies showed that exposure to nanoparticles may affect epigenetic processes, such as DNA methylation, histone modifications, and RNA interference [146], and it is certain that nanoparticles can cause DNA damage [147].

It has been suggested that the cytotoxicity of gold nanoparticles depends mostly on their size [148]. Another study on silver nanoparticles emphasized that size is a very important property because of the cellular uptake of these particles through pores [149]. A few of the most important silver nanoparticles and genotoxicity responses were listed by Manickam et al. [150]. The majority of studies showing nanoparticle toxicity are linked to their use in medicine and pharmacology, while risks concerning food consumption have not been sufficiently studied.

Materials that are harmless to humans may show toxicity if they are nanosized, which leads to doubts whether nanomaterials deserve special regulative frames. A summary of EU and some non-EU countries' legislations about the use of nanomaterials can be found [151]. Nanomaterial toxicity, behavior, and bioaccumulation are the main uncertainties because of the lack of sufficient scientific data. 
This must be overcome, and studies must be carried out in risk-and-exposure assessments regarding the use of nanomaterials [152]. The European Food Safety Authority (EFSA) has published guidance on risk assessment on this topic [153]. This guidance is a result of a detailed revision of the previous version, regarding certain nanospecific aspects. It suggests that the existing definition of engineered nanomaterial should not define the boundaries of risk assessment, which also addresses other type of materials, and it emphasizes the importance for future research to fill the gaps in order to perform accurate nanomaterial safety assessment.

The European Regulation on Registration, Evaluation, Authorization, and Restriction of Chemicals $(\mathrm{REACH})$ has a special committee dealing with nanomaterials [154]. In the United States, the National Organic Standards Board recommended that engineered nanomaterials should be prohibited from food products bearing the USDA Organic label [155].

\subsection{Polyphenol Toxicity}

The biological activity of polyphenols is mostly related to their ability to chelate metals and scavenge free radicals, but they can exhibit pro-oxidant behavior under certain conditions, leading to the formation of reactive oxygen species that can damage DNA, lipids, and other biomolecules [156]. Antioxidant/prooxidant activity depends on several factors, such as the presence of redox active chemicals, biological-tissue $\mathrm{pH}$, and solubility characteristics [156]. It has been shown that consumption of tea in high doses leads to an imbalance in the antioxidant and pro-oxidant behavior of tea flavonoids, thus resulting in detrimental effects to human health, including the hepatotoxicity of catechins from green tea, the reduction of intestinal absorption of dietary iron, and the precipitation of digestive enzymes by tannins from black tea, and the reduction of lipase activity by polyphenols from oolong tea [138]. According to a scientific opinion on the safety of green-tea catechins given by the EFSA ANS Panel [157], the consumption of green-tea catechins from green-tea infusions and similar drinks is generally safe, but the intake of EGCG as a food supplement in doses equal to or above $800 \mathrm{mg} / \mathrm{day}$ for four months and longer statistically significantly increases serum transaminases in human blood, which indicates liver injury.

Besides pro-oxidant activity, the complexation of bioelements by polyphenol compounds was also observed, which can negatively impact human health. It has been reported that phenolic acids, cyanidin derivatives, delphinidin, quercetin, kaempferol, morin, epigallocatechin-3-gallate, and curcumin are capable of binding bioelements (Fe, $\mathrm{Mg}, \mathrm{Mn}, \mathrm{Zn}, \mathrm{Se}, \mathrm{Co}$, and $\mathrm{Cu}$ ), and thus decrease their absorption in the gastrointestinal tract and, hence, their content in blood and tissue, which can lead to a disorder of bioelement-dependant metabolic pathways [158].

The general conclusion is that nanomaterials are not a uniform group when it comes to risks, even though they have many potential beneficial applications in the food sector; before utilization, they have to pass serious tests. Furthermore, the intake of polyphenols in high doses for a long period of time has harmful effects to humans. The toxicity of polyphenols encapsulated as nanoparticles is still not reported, and there is evidence that the coadministration of polyphenols (quercetin) with ENPs (silver nanoparticles) reduces the harmful effects of ENPs, such as cytotoxicity and oxidative stress [159]. However, further studies should be conducted to estimate the potential toxic effects of polyphenol-loaded nanoparticles.

\section{Conclusions}

The development of nanosized functional food ingredients containing polyphenols has resulted in improvements in food safety and quality, smart packaging, the targeted delivery of compounds, and the improved sensory properties of food product. Most frequently encapsulated polyphenols are catechins, quercetin, eugenol, epigallocatechin, EGCG, curcumin, and tea polyphenols. Nanoparticles such as cyclodextrins, gelatin, casein and whey proteins, zein, chitosan, or complex nanoparticles are generally used as nanocarriers. These carriers protect sensitive polyphenols and preserve beneficial polyphenolic properties. Thanks to their nanosize, the delivery of these particles is upgraded. However, 
the possible toxicity of nanomaterials, such as ENPs, which are used in food-packaging materials, should be addressed, and future work should be focused on the validation of relevant methods for the characterization of nanomaterials in complex matrices, and for measuring their reactivity and in vitro degradation, in order to facilitate safety-risk assessments. Another approach could be the use of native nanocarriers, such as casein micelles, for which the GRAS status is verified. It should be kept in mind that numerous health claims related to polyphenols have failed to be demonstrated in vivo studies, and the intake of polyphenols may pose health risks in high doses. Certainly, knowledge of nanotechnology and polyphenols and awareness of their benefits and risks should be increased.

Author Contributions: All authors participated in the creation and conceptualization of the article; D.D.M., D.A.P., and A.Ž.K. conducted the literature search; writing—original draft preparation, writing-review and editing were carried out by D.D.M., D.A.P., S.M.L., and M.B.P.; supervision was carried out by V.A.N., Ž.L.T., and M.B.P.

Funding: This research was funded by the Ministry of Education, Science, and Technological Development of the Republic of Serbia, Project TR 31069, OI 172017, III 46001, III 46009, and III 46010.

Acknowledgments: D.D.M. and D.A.P. are recipients of the grants for PhD study and a contract from the Ministry of Education, Science, and Technological Development of Republic of Serbia (Project TR 31069).

Conflicts of Interest: The authors declare no conflicts of interest.

\section{References}

1. Acevedo-Fani, A.; Soliva-Fortuny, R.; Martín-Belloso, O. Nanostructured emulsions and nanolaminates for delivery of active ingredients: Improving food safety and functionality. Trends Food Sci. Technol. 2017, 60, 12-22. [CrossRef]

2. Faridi Esfanjani, A.; Jafari, S.M. Biopolymer nano-particles and natural nano-carriers for nano-encapsulation of phenolic compounds. Colloids Surf. B Biointerfaces 2016, 146, 532-543. [CrossRef] [PubMed]

3. Huang, Q.; Yu, H.; Ru, Q. Bioavailability and delivery of nutraceuticals using nanotechnology. J. Food Sci. 2010, 75, R50-R57. [CrossRef] [PubMed]

4. McClements, D.J.; Decker, E.A.; Park, Y.; Weiss, J. Structural design principles for delivery of bioactive components in nutraceuticals and functional foods. Crit. Rev. Food Sci. Nutr. 2009, 49, 577-606. [CrossRef]

5. Ranjan, S.; Dasgupta, N.; Chakraborty, A.R.; Melvin Samuel, S.; Ramalingam, C.; Shanker, R.; Kumar, A. Nanoscience and nanotechnologies in food industries: Opportunities and research trends. J. Nanopart. Res. 2014, 16, 2464. [CrossRef]

6. Dasgupta, N.; Ranjan, S. Nanotechnology in Food Sector. In An Introduction to Food Grade Nanoemulsions; Dasgupta, N., Ranjan, S., Eds.; Springer: Singapore, 2018; pp. 1-18. [CrossRef]

7. Ummi, A.S.; Siddiquee, S. Chapter 15-Nanotechnology Applications in Food: Opportunities and Challenges in Food Industry. In Applications in Energy, Drug and Food; Siddiquee, S., Hong, M.G.J., Rahman, M.M., Eds.; Springer International Publishing: Cham, Switzerland, 2019; pp. 298-308. [CrossRef]

8. Neo, Y.P.; Ray, S.; Jin, J.; Gizdavic-Nikolaidis, M.; Nieuwoudt, M.K.; Liu, D.; Quek, S.Y. Encapsulation of food grade antioxidant in natural biopolymer by electrospinning technique: A physicochemical study based on zein-gallic acid system. Food Chem. 2013, 136, 1013-1021. [CrossRef] [PubMed]

9. Sanguansri, P.; Augustin, M.A. Nanoscale materials development-A food industry perspective. Trends Food Sci. Technol. 2006, 17, 547-556. [CrossRef]

10. Ahmad, S.; Munir, S.; Zeb, N.; Ullah, A.; Khan, B.; Ali, J.; Bilal, M.; Omer, M.; Alamzeb, M.; Salman, S.M.; et al. Green nanotechnology: A review on green synthesis of silver nanoparticles-An ecofriendly approach. Int. J. Nanomed. 2019, 14, 5087-5107. [CrossRef]

11. Nasrollahzadeh, M.; Sajadi, S.M.; Sajjadi, M.; Issaabadi, Z. Chapter 1-An Introduction to Nanotechnology. In An Introduction to Green Nanotechnology; Nasrollahzadeh, M., Sajadi, S.M., Sajjadi, M., Issaabadi, Z., Atarod, M., Eds.; Elsevier: Amsterdam, The Netherlands, 2019; Volume 28, pp. 1-27.

12. Sanjay, S.S. Chapter 2-Safe nano is green nano. In Green Synthesis, Characterization and Applications of Nanoparticles; Shukla, A.K., Iravani, S., Eds.; Elsevier: Amsterdam, The Netherlands, 2019; pp. 27-36. [CrossRef]

13. Ramachandraiah, K.; Han, S.G.; Chin, K.B. Nanotechnology in meat processing and packaging: Potential applications-A review. Asian-Australas. J. Anim. Sci. 2015, 28, 290-302. [CrossRef] 
14. Ozogul, Y.; Yuvka, İ.; Ucar, Y.; Durmus, M.; Kösker, A.R.; Öz, M.; Ozogul, F. Evaluation of effects of nanoemulsion based on herb essential oils (rosemary, laurel, thyme and sage) on sensory, chemical and microbiological quality of rainbow trout (Oncorhynchus mykiss) fillets during ice storage. LWT 2017, 75, 677-684. [CrossRef]

15. Mangiacapra, P.; Gorrasi, G.; Sorrentino, A.; Vittoria, V. Biodegradable nanocomposites obtained by ball milling of pectin and montmorillonites. Carbohydr. Polym. 2006, 64, 516-523. [CrossRef]

16. Giosafatto, C.V.L.; Sabbah, M.; Al-Asmar, A.; Esposito, M.; Sanchez, A.; Villalonga Santana, R.; Cammarota, M.; Mariniello, L.; Di Pierro, P.; Porta, R. Effect of Mesoporous Silica Nanoparticles on Glycerol-Plasticized Anionic and Cationic Polysaccharide Edible Films. Coatings 2019, 9, 172. [CrossRef]

17. Handford, C.E.; Dean, M.; Spence, M.; Henchion, M.; Elliott, C.T.; Campbell, K. Awareness and attitudes towards the emerging use of nanotechnology in the agri-food sector. Food Control 2015, 57, 24-34. [CrossRef]

18. Alrgei, H.O.S.; Dabić, D.Č.; Natić, M.M.; Rakonjac, V.S.; Milojković-Opsenica, D.; Tešić, Ž.L.; Fotirić Akšić, M.M. Chemical profile of major taste- and health-related compounds of Oblačinska sour cherry. J. Sci. Food Agric. 2016, 96, 1241-1251. [CrossRef]

19. Stanisavljević, N.S.; Ilić, M.D.; Matić, I.Z.; Jovanović, Ž.S.; Čupić, T.; Dabić, D.Č.; Natić, M.M.; Tešić, Ž.L. Identification of Phenolic Compounds from Seed Coats of Differently Colored European Varieties of Pea (Pisum sativum L.) and Characterization of Their Antioxidant and In Vitro Anticancer Activities. Nutr. Cancer 2016, 68, 988-1000. [CrossRef]

20. Cvetanović, A.; Švarc-Gajić, J.; Gašić, U.; Tešić, Ž.; Zengin, G.; Zeković, Z.; Đurović, S. Isolation of apigenin from subcritical water extracts: Optimization of the process. J. Supercrit. Fluids 2017, 120, 32-42. [CrossRef]

21. Fotirić Akšić, M.M.; Dabić, D.Č.; Gašić, U.M.; Zec, G.N.; Vulić, T.B.; Tešić, Ž.L.; Natić, M.M. Polyphenolic Profile of Pear Leaves with Different Resistance to Pear Psylla (Cacopsylla pyri). J. Agric. Food Chem. 2015, 63, 7476-7486. [CrossRef]

22. Kostić, A.Ž.; Gašić, U.M.; Pešić, M.B.; Stanojević, S.P.; Barać, M.B.; Mačukanović-Jocić, M.P.; Avramov, S.N.; Tešić, Ž.L. Phytochemical Analysis and Total Antioxidant Capacity of Rhizome, Above-Ground Vegetative Parts and Flower of Three Iris Species. Chem. Biodivers. 2019, 16, e1800565. [CrossRef]

23. Kostić, A.Ž. Polyphenolic profile and antioxidant properties of bee-collected pollen from sunflower (Helianthus annuus L.) plant. LWT Food Sci. Technol. 2019, 112, 108244. [CrossRef]

24. Mišić, D.; Šiler, B.; Gašić, U.; Avramov, S.; Živković, S.; Nestorović Živković, J.; Milutinović, M.; Tešić, Ž. Simultaneous UHPLC/DAD/(+/-)HESI-MS/MS Analysis of Phenolic Acids and Nepetalactones in Methanol Extracts of Nepeta Species: A Possible Application in Chemotaxonomic Studies. Phytochem. Anal. 2015, 26, 72-85. [CrossRef]

25. Natić, M.M.; Dabić, D.Č.; Papetti, A.; Fotirić Akšić, M.M.; Ognjanov, V.; Ljubojević, M.; Tešić, Ž.L. Analysis and characterisation of phytochemicals in mulberry (Morus alba L.) fruits grown in Vojvodina, North Serbia. Food Chem. 2015, 171, 128-136. [CrossRef] [PubMed]

26. Pantelić, M.M.; Dabić Zagorac, D.Č.; Davidović, S.M.; Todić, S.R.; Bešlić, Z.S.; Gašić, U.M.; Tešić, Ž.L.; Natić, M.M. Identification and quantification of phenolic compounds in berry skin, pulp, and seeds in 13 grapevine varieties grown in Serbia. Food Chem. 2016, 211, 243-252. [CrossRef] [PubMed]

27. Pavlović, A.V.; Papetti, A.; Dabić Zagorac, D.Č.; Gašić, U.M.; Mišić, D.M.; Tešić, Ž.L.; Natić, M.M. Phenolics composition of leaf extracts of raspberry and blackberry cultivars grown in Serbia. Ind. Crops Prod. 2016, 87, 304-314. [CrossRef]

28. Ristivojević, P.; Trifković, J.; Gašić, U.; Andrić, F.; Nedić, N.; Tešić, Ž.; Milojković-Opsenica, D. Ultrahigh-performance Liquid Chromatography and Mass Spectrometry (UHPLC-LTQ/Orbitrap/MS/MS) study of phenolic profile of Serbian poplar type propolis. Phytochem. Anal. 2015, 26, 127-136. [CrossRef] [PubMed]

29. Stanisavljević, N.S.; Ilić, M.; Jovanović, Z.S.; Čupić, T.; Dabić, D.C.; Natić, M.M.; Tešić, Z.L.; Radović, S.S. Identification of seed coat phenolic compounds from differently colored pea varieties and characterization of their antioxidant activity. Arch. Biol. Sci. 2015, 67, 829-840. [CrossRef]

30. Pešić, M.B.; Milinčić, D.D.; Kostić, A.Ž.; Stanisavljević, N.S.; Vukotić, G.N.; Kojić, M.O.; Gašić, U.M.; Barać, M.B.; Stanojević, S.P.; Popović, D.A.; et al. In vitro digestion of meat- and cereal-based food matrix enriched with grape extracts: How are polyphenol composition, bioaccessibility and antioxidant activity affected? Food Chem. 2019, 284, 28-44. [CrossRef] [PubMed] 
31. Gómez-Estaca, J.; Balaguer, M.; Gavara, R.; Hernandez-Munoz, P. Formation of zein nanoparticles by electrohydrodynamic atomization: Effect of the main processing variables and suitability for encapsulating the food coloring and active ingredient curcumin. Food Hydrocoll. 2012, 28, 82-91. [CrossRef]

32. Madureira, A.R.; Pereira, A.; Castro, P.M.; Pintado, M. Production of antimicrobial chitosan nanoparticles against food pathogens. J. Food Eng. 2015, 167, 210-216. [CrossRef]

33. Aguirre, A.; Borneo, R. Chapter 4-Improving Bioavailability of Polyphenols Using Nanodelivery Systems Based on Food Polymers. In Polyphenols in Plants (Second Edition); Watson, R.R., Ed.; Academic Press: Cambridge, MA, USA, 2019; pp. 59-65. [CrossRef]

34. Hu, B.; Liu, X.; Zhang, C.; Zeng, X. Food macromolecule based nanodelivery systems for enhancing the bioavailability of polyphenols. J. Food Drug Anal. 2017, 25, 3-15. [CrossRef]

35. Liu, F.; Antoniou, J.; Li, Y.; Yi, J.; Yokoyama, W.; Ma, J.; Zhong, F. Preparation of gelatin films incorporated with tea polyphenol nanoparticles for enhancing controlled-release antioxidant properties. J. Agric. Food Chem. 2015, 63, 3987-3995. [CrossRef]

36. Chen, Y.-C.; Yu, S.-H.; Tsai, G.-J.; Tang, D.-W.; Mi, F.-L.; Peng, Y.-P. Novel Technology for the Preparation of Self-Assembled Catechin/Gelatin Nanoparticles and Their Characterization. J. Agric. Food Chem. 2010, 58, 6728-6734. [CrossRef] [PubMed]

37. Prakash Upputuri, R.T.; Azad Mandal, A.K. Sustained Release of Green Tea Polyphenols from Liposomal Nanoparticles; Release Kinetics and Mathematical Modelling. Iran. J. Biotechnol. 2017, 15, 277-283. [CrossRef] [PubMed]

38. Tian, B.; Wang, Y.; Wang, T.; Mao, L.; Lu, Y.; Wang, H.; Feng, Z. Structure and Functional Properties of Antioxidant Nanoemulsions Prepared with Tea Polyphenols and Soybean Protein Isolate. J. Oleo Sci. 2019, 68, 689-697. [CrossRef] [PubMed]

39. Wang, M.; Fu, Y.; Chen, G.; Shi, Y.; Li, X.; Zhang, H.; Shen, Y. Fabrication and characterization of carboxymethyl chitosan and tea polyphenols coating on zein nanoparticles to encapsulate $\beta$-carotene by anti-solvent precipitation method. Food Hydrocoll. 2018, 77, 577-587. [CrossRef]

40. Liang, J.; Yan, H.; Puligundla, P.; Gao, X.; Zhou, Y.; Wan, X. Applications of chitosan nanoparticles to enhance absorption and bioavailability of tea polyphenols: A review. Food Hydrocoll. 2017, 69, 286-292. [CrossRef]

41. Pimentel-Moral, S.; Teixeira, M.C.; Fernandes, A.R.; Arraez-Roman, D.; Martinez-Ferez, A.; Segura-Carretero, A.; Souto, E.B. Lipid nanocarriers for the loading of polyphenols-A comprehensive review. Adv. Colloid Interface Sci. 2018, 260, 85-94. [CrossRef]

42. Balanč, B.; Trifkovic, K.; Pravilović, R.; Đorđević, V.; Levic, S.; Bugarski, B.; Nedovic, V. Chapter 16-Lipid Nanocarriers for Phytochemical Delivery in Foods. In Nanotechnology Applications in the Food Industry; Ravishankar Rai, V., Bai, J.A., Eds.; CRC Press: Boca Raton, FL, USA, 2018; pp. 357-384. [CrossRef]

43. Chang, C.; Wang, T.; Hu, Q.; Luo, Y. Caseinate-zein-polysaccharide complex nanoparticles as potential oral delivery vehicles for curcumin: Effect of polysaccharide type and chemical cross-linking. Food Hydrocoll. 2017, 72, 254-262. [CrossRef]

44. Kalušević, A.M.; Lević, S.M.; Čalija, B.R.; Milić, J.R.; Pavlović, V.B.; Bugarski, B.M.; Nedović, V.A. Effects of different carrier materials on physicochemical properties of microencapsulated grape skin extract. J. Food Sci. Technol. 2017, 54, 3411-3420. [CrossRef]

45. Liang, J.; Yan, H.; Yang, H.J.; Kim, H.W.; Wan, X.; Lee, J.; Ko, S. Synthesis and controlled-release properties of chitosan/beta-Lactoglobulin nanoparticles as carriers for oral administration of epigallocatechin gallate. Food Sci. Biotechnol. 2016, 25, 1583-1590. [CrossRef]

46. Jones, O.G.; McClements, D.J. Recent progress in biopolymer nanoparticle and microparticle formation by heat-treating electrostatic protein-polysaccharide complexes. Adv. Colloid Interface Sci. 2011, 167, 49-62. [CrossRef]

47. Turgeon, S.; Schmitt, C.; Sanchez, C. Protein-Polysaccharide complexes and coacervates. Curr. Opin. Colloid Interface Sci. 2007, 12, 166-178. [CrossRef]

48. Veneranda, M.; Hu, Q.; Wang, T.; Luo, Y.; Castro, K.; Madariaga, J.M. Formation and characterization of zein-caseinate-pectin complex nanoparticles for encapsulation of eugenol. LWT 2018, 89, 596-603. [CrossRef]

49. Luo, Y.; Pan, K.; Zhong, Q. Casein/pectin nanocomplexes as potential oral delivery vehicles. Int. J. Pharm. 2015, 486, 59-68. [CrossRef] 
50. Hu, B.; Ting, Y.; Zeng, X.; Huang, Q. Cellular uptake and cytotoxicity of chitosan-caseinophosphopeptides nanocomplexes loaded with epigallocatechin gallate. Carbohydr. Polym. 2012, 89, 362-370. [CrossRef] [PubMed]

51. Silva, H.D.; Cerqueira, M.Â.; Vicente, A.A. Erratum to: Nanoemulsions for Food Applications: Development and Characterization. Food Bioprocess Technol. 2014, 7, 306. [CrossRef]

52. Chang, C.; Wang, T.; Hu, Q.; Zhou, M.; Jingyi, X.; Luo, Y. Pectin coating improves physicochemical properties of caseinate/zein nanoparticles as oral delivery vehicles for curcumin. Food Hydrocoll. 2017, 70, 143-151. [CrossRef]

53. Ramalingam, P.; Yoo, S.W.; Ko, Y.T. Nanodelivery systems based on mucoadhesive polymer coated solid lipid nanoparticles to improve the oral intake of food curcumin. Food Res. Int. 2016, 84, 113-119. [CrossRef]

54. Tang, D.-W.; Yu, S.-H.; Ho, Y.-C.; Huang, B.-Q.; Tsai, G.-J.; Hsieh, H.-Y.; Sung, H.-W.; Mi, F.-L. Characterization of tea catechins-loaded nanoparticles prepared from chitosan and an edible polypeptide. Food Hydrocoll. 2013, 30, 33-41. [CrossRef]

55. Dube, A.; Nicolazzo, J.A.; Larson, I. Chitosan nanoparticles enhance the intestinal absorption of the green tea catechins (+)-catechin and (-)-epigallocatechin gallate. Eur. J. Pharm. Sci. 2010, 41, 219-225. [CrossRef]

56. Dudhani, A.R.; Kosaraju, S.L. Bioadhesive chitosan nanoparticles: Preparation and characterization. Carbohydr. Polym. 2010, 81, 243-251. [CrossRef]

57. Liang, J.; Li, F.; Fang, Y.; Yang, W.; An, X.; Zhao, L.; Xin, Z.; Cao, L.; Hu, Q. Synthesis, characterization and cytotoxicity studies of chitosan-coated tea polyphenols nanoparticles. Colloids Surf. B Biointerfaces 2011, 82, 297-301. [CrossRef] [PubMed]

58. Aluani, D.; Tzankova, V.; Kondeva-Burdina, M.; Yordanov, Y.; Nikolova, E.; Odzhakov, F.; Apostolov, A.; Markova, T.; Yoncheva, K. Evaluation of biocompatibility and antioxidant efficiency of chitosan-alginate nanoparticles loaded with quercetin. Int. J. Biol. Macromol. 2017, 103, 771-782. [CrossRef] [PubMed]

59. Kumari, A.; Yadav, S.K.; Pakade, Y.B.; Singh, B.; Yadav, S.C. Development of biodegradable nanoparticles for delivery of quercetin. Colloids Surf. B Biointerfaces 2010, 80, 184-192. [CrossRef] [PubMed]

60. Li, H.; Zhao, X.; Ma, Y.; Zhai, G.; Li, L.; Lou, H. Enhancement of gastrointestinal absorption of quercetin by solid lipid nanoparticles. J. Control. Release 2009, 133, 238-244. [CrossRef]

61. Dube, A.; Nicolazzo, J.; Larson, I. Chitosan nanoparticles enhance the plasma exposure of (-)-epigallocatechin gallate in mice through an enhancement in intestinal stability. Eur. J. Pharm. Sci. 2011, 44, 422-426. [CrossRef]

62. Moeiniafshari, A.-A.; Zarrabi, A.; Bordbar, A.-K. Exploring the interaction of naringenin with bovine beta-casein nanoparticles using spectroscopy. Food Hydrocoll. 2015, 51, 1-6. [CrossRef]

63. Morsy, M.K.; Mekawi, E.; Elsabagh, R. Impact of pomegranate peel nanoparticles on quality attributes of meatballs during refrigerated storage. LWT 2018, 89, 489-495. [CrossRef]

64. Pereira, M.C.; Oliveira, D.A.; Hill, L.E.; Zambiazi, R.C.; Borges, C.D.; Vizzotto, M.; Mertens-Talcott, S.; Talcott, S.; Gomes, C.L. Effect of nanoencapsulation using PLGA on antioxidant and antimicrobial activities of guabiroba fruit phenolic extract. Food Chem. 2018, 240, 396-404. [CrossRef]

65. Zhang, Y.; Niu, Y.; Luo, Y.; Ge, M.; Yang, T.; Yu, L.; Wang, Q. Fabrication, characterization and antimicrobial activities of thymol-loaded zein nanoparticles stabilized by sodium caseinate-chitosan hydrochloride double layers. Food Chem. 2014, 142, 269-275. [CrossRef]

66. Engel, J.B.; Heckler, C.; Tondo, E.C.; Daroit, D.J.; da Silva Malheiros, P. Antimicrobial activity of free and liposome-encapsulated thymol and carvacrol against Salmonella and Staphylococcus aureus adhered to stainless steel. Int. J. Food Microbiol. 2017, 252, 18-23. [CrossRef]

67. da Rosa, C.G.; de Oliveira Brisola Maciel, M.V.; de Carvalho, S.M.; de Melo, A.P.Z.; Jummes, B.; da Silva, T.; Martelli, S.M.; Villetti, M.A.; Bertoldi, F.C.; Barreto, P.L.M. Characterization and evaluation of physicochemical and antimicrobial properties of zein nanoparticles loaded with phenolics monoterpenes. Colloids Surf. A Physicochem. Eng. Asp. 2015, 481, 337-344. [CrossRef]

68. Ghosh, V.; Mukherjee, A.; Chandrasekaran, N. Eugenol-loaded antimicrobial nanoemulsion preserves fruit juice against, microbial spoilage. Colloids Surf. B Biointerfaces 2014, 114, 392-397. [CrossRef] [PubMed]

69. Hu, Q.; Gerhard, H.; Upadhyaya, I.; Venkitanarayanan, K.; Luo, Y. Antimicrobial eugenol nanoemulsion prepared by gum arabic and lecithin and evaluation of drying technologies. Int. J. Biol. Macromol. 2016, 87, 130-140. [CrossRef] [PubMed] 
70. Granja, A.; Vieira, A.C.; Chaves, L.L.; Nunes, C.; Neves, A.R.; Pinheiro, M.; Reis, S. Folate-targeted nanostructured lipid carriers for enhanced oral delivery of epigallocatechin-3-gallate. Food Chem. 2017, 237, 803-810. [CrossRef]

71. Dahiya, S.; Rani, R.; Dhingra, D.; Kumar, S.; Dilbaghi, N. Conjugation of epigallocatechin gallate and piperine into a zein nanocarrier: Implication on antioxidant and anticancer potential. Adv. Nat. Sci. Nanosci. Nanotechnol. 2018, 9, 035011. [CrossRef]

72. Dobrucka, R.; Kaczmarek, M.; Dlugaszewska, J. Cytotoxic and antimicrobial effect of biosynthesized silver nanoparticles using the fruit extract of Ribes nigrum. Adv. Nat. Sci. Nanosci. Nanotechnol. 2018, 9, 025015. [CrossRef]

73. Ghayour, N.; Hosseini, S.M.H.; Eskandari, M.H.; Esteghlal, S.; Nekoei, A.-R.; Hashemi Gahruie, H.; Tatar, M.; Naghibalhossaini, F. Nanoencapsulation of quercetin and curcumin in casein-based delivery systems. Food Hydrocoll. 2019, 87, 394-403. [CrossRef]

74. Khan, M.A.; Yue, C.; Fang, Z.; Hu, S.; Cheng, H.; Bakry, A.M.; Liang, L. Alginate/chitosan-coated zein nanoparticles for the delivery of resveratrol. J. Food Eng. 2019, 258, 45-53. [CrossRef]

75. Chang, Y.; McClements, D.J. Optimization of Orange Oil Nanoemulsion Formation by Isothermal Low-Energy Methods: Influence of the Oil Phase, Surfactant, and Temperature. J. Agric. Food Chem. 2014, 62, 2306-2312. [CrossRef]

76. Chang, Y.; McLandsborough, L.; McClements, D.J. Physical Properties and Antimicrobial Efficacy of Thyme Oil Nanoemulsions: Influence of Ripening Inhibitors. J. Agric. Food Chem. 2012, 60, 12056-12063. [CrossRef]

77. Schwarz, B.; Hofmann, T. Is there a direct relationship between oral astringency and human salivary protein binding. Eur. Food Res. Technol. 2008, 227, 1693-1698. [CrossRef]

78. Jöbstl, E.; O'Connell, J.; Fairclough, J.P.A.; Williamson, M.P. Molecular Model for Astringency Produced by Polyphenol/Protein Interactions. Biomacromolecules 2004, 5, 942-949. [CrossRef] [PubMed]

79. Zhang, H.; Jung, J.; Zhao, Y. Preparation, characterization and evaluation of antibacterial activity of catechins and catechins-Zn complex loaded beta-chitosan nanoparticles of different particle sizes. Carbohydr. Polym. 2016, 137, 82-91. [CrossRef] [PubMed]

80. Nedović, V.; Kalusević, A.; Manojlović, V.; Lević, S.; Bugarski, B. An overview of encapsulation technologies for food applications. Procedia Food Sci. 2011, 1, 1806-1815. [CrossRef]

81. Popović, D.A.; Milinčić, D.D.; Pešić, M.B.; Kalušević, A.M.; Tešić, Ž.Lj.; Nedović, V.A. Chapter 12-Encapsulation technologies for polyphenol-loaded microparticles in food industry. In Green Food Processing Techniques: Preservation, Transformation and Extraction; Chemat, F., Eugene, V., Eds.; Academic Press: Cambridge, MA, USA, 2019; pp. 335-368. [CrossRef]

82. Sarkar, P.; Choudhary, R.; Panigrahi, S.; Syed, I.; Sivapratha, S.; Dhumal, C.V. Nano-inspired systems in food technology and packaging. Environ. Chem. Lett. 2017, 15, 607-622. [CrossRef]

83. Zhang, H.; Chen, S. Chapter 32: Nanoparticle-based methods for food safety evaluation. In Evaluation Technologies for Food Quality; Zhong, J., Wang, X., Eds.; Woodhead Publishing: Sawston, UK, 2019; pp. 817-835. [CrossRef]

84. Lević, S.; Djordjević, V.; Rajić, N.; Milivojević, M.; Bugarski, B.; Nedović, V. Entrapment of ethyl vanillin in calcium alginate and calcium alginate/poly(vinyl alcohol) beads. Chem. Pap. 2013, 67, 221-228. [CrossRef]

85. Isailović, B.; Djordjević, V.; Lević, S.; Milanović, J.; Bugarski, B.; Nedović, V. Encapsulation of flavors and aromas: Controlled release. In Edible Films and Coatings: Fundamentals and Applications; CRC Press: Boca Raton, FL, USA, 2016; pp. 317-344. [CrossRef]

86. Wang, Y.; Lu, Z.; Lv, F.; Bie, X. Study on microencapsulation of curcumin pigments by spray drying. Eur. Food Res. Technol. 2009, 229, 391-396. [CrossRef]

87. Tonnesen, H.H. Solubility, chemical and photochemical stability of curcumin in surfactant solutions. Studies of curcumin and curcuminoids, XXVIII. Die Pharm. 2002, 57, 820-824.

88. Serpa Guerra, A.M.; Gómez Hoyos, C.; Velásquez-Cock, J.A.; Vélez Acosta, L.; Gañán Rojo, P.; Velásquez Giraldo, A.M.; Zuluaga Gallego, R. The nanotech potential of turmeric (Curcuma longa L.) in food technology: A review. Crit. Rev. Food Sci. Nutr. 2019, 24, 1-13. [CrossRef]

89. Dalgleish, D.G. Chapter 3-The Basis of Structure in Dairy-Based Foods: Casein Micelles and their Properties. In Food Structures, Digestion and Health; Boland, M., Golding, M., Singh, H., Eds.; Academic Press: San Diego, CA, USA, 2014; pp. 83-105. [CrossRef] 
90. Pesić, M.B.; Barać, M.B.; Stanojević, S.P.; Ristić, N.M.; Macej, O.D.; Vrvić, M.M. Heat induced casein-whey protein interactions at natural $\mathrm{pH}$ of milk: A comparison between caprine and bovine milk. Small Rumin. Res. 2012, 108, 77-86. [CrossRef]

91. Pesić, M.B.; Barać, M.B.; Stanojević, S.P.; Vrvić, M.M. Effect of pH on heat-induced casein-whey protein interactions: A comparison between caprine milk and bovine milk. Int. Dairy J. 2014, 39, 178-183. [CrossRef]

92. Pesić, M.B.; Barać, M.B.; Stanojević, S.P.; Vrvić, M.M. Chapter 9-Heat-Induced Casein-Whey Protein Interactions in Caprine Milk: Whether Are Similar to Bovine Milk? In Emerging and Traditional Technologies for Safe, Healthy and Quality Food; Nedovic, V., Raspor, P., Levic, J., Tumbas, V., Barbosa-Cánovas, G., Eds.; Springer International Publishing: Cham, Switzerland, 2016; pp. 163-175. [CrossRef]

93. Moeller, H.; Martin, D.; Schrader, K.; Hoffmann, W.; Lorenzen, P.C. Native casein micelles as nanocarriers for $\beta$-carotene: $\mathrm{pH}$-and temperature-induced opening of the micellar structure. Int. J. Food Sci. Technol. 2017, 52, 1122-1130. [CrossRef]

94. Moeller, H.; Martin, D.; Schrader, K.; Hoffmann, W.; Lorenzen, P.C. Spray- or freeze-drying of casein micelles loaded with Vitamin D2: Studies on storage stability and in vitro digestibility. LWT 2018, 97, 87-93. [CrossRef]

95. Haratifar, S.; Corredig, M. Interactions between tea catechins and casein micelles and their impact on renneting functionality. Food Chem. 2014, 143, 27-32. [CrossRef]

96. O'Connell, J.E.; Fox, P.D.; Tan-Kintia, R.; Fox, P.F. Effects of Tea, Coffee and Cocoa Extracts on the Colloidal Stability of Milk and Concentrated Milk. Int. Dairy J. 1998, 8, 689-693. [CrossRef]

97. Food and Drug Administration (FDA). Select Committee on GRAS Substances (SCOGS) Opinion: Calcium Caseinate; Casein; Sodium Caseinate. 2015. Available online: http://wayback.archive-it.org/7993/20171031061247/ https:/www.fda.gov/Food/IngredientsPackagingLabeling/GRAS/SCOGS/ucm20171031260879.htm (accessed on 19 September 2019).

98. Hu, B.; Pan, C.; Sun, Y.; Hou, Z.; Ye, H.; Zeng, X. Optimization of fabrication parameters to produce chitosan-tripolyphosphate nanoparticles for delivery of tea catechins. J. Agric. Food Chem. 2008, 56, 7451-7458. [CrossRef]

99. Peng, G.; Wargovich, M.J.; Dixon, D.A. Anti-proliferative effects of green tea polyphenol EGCG on Ha-Ras-induced transformation of intestinal epithelial cells. Cancer Lett. 2006, 238, 260-270. [CrossRef]

100. Puligundla, P.; Mok, C.; Ko, S.; Liang, J.; Recharla, N. Nanotechnological approaches to enhance the bioavailability and therapeutic efficacy of green tea polyphenols. J. Funct. Foods 2017, 34, 139-151. [CrossRef]

101. Lante, A.; Friso, D. Oxidative stability and rheological properties of nanoemulsion with ultrasonic extracted green tea infusion. Food Res. Int. 2013, 54, 269-276. [CrossRef]

102. Zou, L.; Peng, S.; Liu, W.; Chen, X.; Liu, C. A novel delivery system dextran sulfate coated amphiphilic chitosan derivatives-based nanoliposome: Capacity to improve in vitro digestion stability of (-)-epigallocatechin gallate. Food Res. Int. 2015, 69, 114-120. [CrossRef]

103. Liu, C.; Zhang, Z.; Kong, Q.; Zhang, R.; Yang, X. Enhancing the antitumor activity of tea polyphenols encapsulated in biodegradable nanogels by macromolecular self-assembly. RSC Adv. 2019, 9, 10004-10016. [CrossRef]

104. Wu, J.; Wang, Y.; Yang, H.; Liu, X.; Lu, Z. Preparation and biological activity studies of resveratrol loaded ionically cross-linked chitosan-TPP nanoparticles. Carbohydr. Polym. 2017, 175, 170-177. [CrossRef] [PubMed]

105. Natesan, S.; Pandian, S.; Ponnusamy, C.; Palanichamy, R.; Muthusamy, S.; Kandasamy, R. Co-encapsulated resveratrol and quercetin in chitosan and peg modified chitosan nanoparticles: For efficient intra ocular pressure reduction. Int. J. Biol. Macromol. 2017, 104, 1837-1845. [CrossRef] [PubMed]

106. Kumar, S.; Sangwan, P.; Lather, V.; Pandita, D. Biocompatible PLGA-oil hybrid nanoparticles for high loading and controlled delivery of resveratrol. J. Drug Deliv. Sci. Technol. 2015, 30, 54-62. [CrossRef]

107. Caddeo, C.; Nacher, A.; Vassallo, A.; Armentano, M.F.; Pons, R.; Fernàndez-Busquets, X.; Carbone, C.; Valenti, D.; Fadda, A.M.; Manconi, M. Effect of quercetin and resveratrol co-incorporated in liposomes against inflammatory/oxidative response associated with skin cancer. Int. J. Pharm. 2016, 513, 153-163. [CrossRef]

108. Fonseca, D.P.; Khalil, N.M.; Mainardes, R.M. Bovine serum albumin-based nanoparticles containing resveratrol: Characterization and antioxidant activity. J. Drug Deliv. Sci. Technol. 2017, 39, 147-155. [CrossRef] 
109. Jung, K.-H.; Lee, J.H.; Park, J.W.; Quach, C.H.T.; Moon, S.-H.; Cho, Y.S.; Lee, K.-H. Resveratrol-loaded polymeric nanoparticles suppress glucose metabolism and tumor growth in vitro and in vivo. Int. J. Pharm. 2015, 478, 251-257. [CrossRef]

110. Musazzi, U.M.; Youm, I.; Murowchick, J.B.; Ezoulin, M.J.; Youan, B.-B.C. Resveratrol-loaded nanocarriers: Formulation, optimization, characterization and in vitro toxicity on cochlear cells. Colloids Surf. B Biointerfaces 2014, 118, 234-242. [CrossRef]

111. Cosco, D.; Paolino, D.; Maiuolo, J.; Marzio, L.D.; Carafa, M.; Ventura, C.A.; Fresta, M. Ultradeformable liposomes as multidrug carrier of resveratrol and 5-fluorouracil for their topical delivery. Int. J. Pharm. 2015, 489, 1-10. [CrossRef]

112. Chauhan, P.; Mahajan, S.; Prasad, G.B.K.S. Preparation and characterization of CS-ZnO-NC nanoparticles for imparting anti-diabetic activities in experimental diabetes. J. Drug Deliv. Sci. Technol. 2019, 52, 738-747. [CrossRef]

113. Granata, G.; Consoli, G.M.L.; Lo Nigro, R.; Geraci, C. Hydroxycinnamic acids loaded in lipid-core nanocapsules. Food Chem. 2018, 245, 551-556. [CrossRef] [PubMed]

114. Silva, S.; Veiga, M.; Costa, E.M.; Oliveira, A.L.S.; Madureira, A.R.; Pintado, M. Nanoencapsulation of Polyphenols towards Dairy Beverage Incorporation. Beverages 2018, 4, 61. [CrossRef]

115. Kuswandi, B. Environmental friendly food nano-packaging. Environ. Chem. Lett. 2017, 15, 205-221. [CrossRef]

116. Devi, K.P.; Nisha, S.A.; Sakthivel, R.; Pandian, S.K. Eugenol (an essential oil of clove) acts as an antibacterial agent against Salmonella typhi by disrupting the cellular membrane. J. Ofethnopharmacol. 2010, 130, 107-115. [CrossRef]

117. Wattanasatcha, A.; Rengpipat, S.; Wanichwecharungruang, S. Thymol nanospheres as an effective anti-bacterial agent. Int. J. Pharm. 2012, 434, 360-365. [CrossRef]

118. Tatli Seven, P.; Seven, I.; Gul Baykalir, B.; Iflazoglu Mutlu, S.; Salem, A.Z.M. Nanotechnology and nano-propolis in animal production and health: An overview. Ital. J. Anim. Sci. 2018, 17, 921-930. [CrossRef]

119. Ahmadi, Z.; Mohammadinejad, R.; Ashrafizadeh, M. Drug delivery systems for resveratrol, a non-flavonoid polyphenol: Emerging evidence in last decades. J. Drug Deliv. Sci. Technol. 2019, 51, 591-604. [CrossRef]

120. Santos, A.C.; Pereira, I.; Pereira-Silva, M.; Ferreira, L.; Caldas, M.; Collado-Gonzalez, M.; Magalhaes, M.; Figueiras, A.; Ribeiro, A.J.; Veiga, F. Nanotechnology-based formulations for resveratrol delivery: Effects on resveratrol in vivo bioavailability and bioactivity. Colloids Surf. B Biointerfaces 2019, 180, 127-140. [CrossRef]

121. Sivasami, P.; Hemalatha, T. Augmentation of therapeutic potential of curcumin using nanotechnology: Current perspectives. Artif. Cells Nanomed. Biotechnol. 2018, 46, 1-12. [CrossRef]

122. Di Costanzo, A.; Angelico, R. Formulation Strategies for Enhancing the Bioavailability of Silymarin: The State of the Art. Molecules 2019, 24, 2155. [CrossRef]

123. Zhang, L.; McClements, D.J.; Wei, Z.; Wang, G.; Liu, X.; Liu, F. Delivery of synergistic polyphenol combinations using biopolymer-based systems: Advances in physicochemical properties, stability and bioavailability. Crit. Rev. Food Sci. Nutr. 2019, 1-15. [CrossRef] [PubMed]

124. Prakash, M.; Basavaraj, B.V.; Chidambara Murthy, K.N. Biological functions of epicatechin: Plant cell to human cell health. Ournal Funct. Foods 2019, 52, 14-24. [CrossRef]

125. Ye, J.-H.; Augustin, M.A. Nano- and micro-particles for delivery of catechins: Physical and biological performance. Crit. Rev. Food Sci. Nutr. 2019, 59, 1563-1579. [CrossRef] [PubMed]

126. European Food Safety Agency Panel on Dietetic Products, Nutrition and Allergies. Scientific Opinion on the substantiation of health claims related to Camellia sinensis (L.) Kuntze (tea), including catechins in green tea and tannins in black tea, and protection of DNA, proteins and lipids from oxidative damage (ID 1103, $1276,1311,1708,2664)$, reduction of acid production in dental plaque (ID 1105, 1111), maintenance of bone (ID 1109), decreasing potentially pathogenic intestinal microorganisms (ID 1116), maintenance of vision (ID 1280), maintenance of normal blood pressure (ID 1546) and maintenance of normal blood cholesterol concentrations (ID 1113, 1114) pursuant to Article 13(1) of Regulation (EC) No 1924/2006. EFSA J. 2010, 8 , 1463. [CrossRef]

127. European Food Safety Agency Panel on Dietetic Products, Nutrition and Allergies. Scientific Opinion on the substantiation of a health claim related to polyphenols in olive and maintenance of normal blood HDL cholesterol concentrations (ID 1639, further assessment) pursuant to Article 13(1) of Regulation (EC) No 1924/2006. EFSA J. 2012, 10, 2848. [CrossRef] 
128. European Food Safety Agency Panel on Dietetic Products, Nutrition and Allergies. Scientific Opinion on the substantiation of health claims related to: Flavonoids and ascorbic acid in fruit juices, including berry juices (ID 1186); flavonoids from citrus (ID 1471); flavonoids from Citrus paradisi Macfad. (ID 3324, 3325); flavonoids (ID 1470, 1693, 1920); flavonoids in cranberry juice (ID 1804); carotenoids (ID 1496, 1621, 1622, 1796); polyphenols (ID 1636, 1637, 1640, 1641, 1642, 1643); rye bread (ID 1179); protein hydrolysate (ID 1646); carbohydrates with a low/reduced glycaemic load (ID 476, 477, 478, 479, 602) and carbohydrates which induce a low/reduced glycaemic response (ID 727, 1122, 1171); alfalfa (ID 1361, 2585, 2722, 2793); caffeinated carbohydrate-containing energy drinks (ID 1272); and soups (ID 1132, 1133) pursuant to Article 13(1) of Regulation (EC) No 1924/2006. EFSA J. 2011, 9, 2082. [CrossRef]

129. Dasgupta, N.; Ranjan, S.; Mundekkad, D.; Chidambaram, R.; Shanker, R.; Kumar, A. Nanotechnology in agro-food: From field to plate. Food Res. Int. 2015, 69, 381-400. [CrossRef]

130. Mlalila, N.; Kadam, D.M.; Swai, H.; Hilonga, A. Transformation of food packaging from passive to innovative via nanotechnology: Concepts and critiques. J. Food Sci. Technol. 2016, 53, 3395-3407. [CrossRef]

131. Salgado, P.R.; Di Giorgio, L.; Musso, Y.S.; Mauri, A.N. Chapter 9-Bioactive Packaging: Combining Nanotechnologies With Packaging for Improved Food Functionality. In Nanomaterials for Food Applications; López Rubio, A., Fabra Rovira, M.J., Martínez Sanz, M., Gómez-Mascaraque, L.G., Eds.; Elsevier: Amsterdam, The Netherlands, 2019; pp. 233-270. [CrossRef]

132. Enescu, D.; Cerqueira, M.A.; Fucinos, P.; Pastrana, L.M. Recent advances and challenges on applications of nanotechnology in food packaging. A literature review. Food Chem. Toxicol. 2019, 134, 110814. [CrossRef]

133. Otoni, C.G.; Moura, M.R.; Aouada, F.A.; Camilloto, G.P.; Cruz, R.S.; Lorevice, M.V.; de Soares, N.F.F.; Mattoso, L.H.C. Antimicrobial and physical-mechanical properties of pectin/papaya puree/cinnamaldehyde nanoemulsion edible composite films. Food Hydrocoll. 2014, 41, 188-194. [CrossRef]

134. Makwana, S.; Choudhary, R.; Dogra, N.; Kohli, P.; Haddock, J. Nanoencapsulation and immobilization of cinnamaldehyde for developing antimicrobial food packaging material. LWT Food Sci. Technol. 2014, 57, 470-476. [CrossRef]

135. Liang, J.; Yan, H.; Wang, X.; Zhou, Y.; Gao, X.; Puligundla, P.; Wan, X. Encapsulation of epigallocatechin gallate in zein/chitosan nanoparticles for controlled applications in food systems. Food Chem. 2017, 231, 19-24. [CrossRef] [PubMed]

136. Wrona, M.; Cran, M.J.; Nerín, C.; Bigger, S.W. Development and characterisation of HPMC films containing PLA nanoparticles loaded with green tea extract for food packaging applications. Carbohydr. Polym. 2017, 156, 108-117. [CrossRef] [PubMed]

137. Salević, A.; Prieto, C.; Cabedo, L.; Nedović, V.; Lagaron, J.M. Physicochemical, Antioxidant and Antimicrobial Properties of Electrospun Poly ( $\varepsilon$-caprolactone) Films Containing a Solid Dispersion of Sage (Salvia officinalis L.) Extract. Nanomaterials 2019, 9, 270. [CrossRef] [PubMed]

138. Jain, A.; Manghani, C.; Kohli, S.; Nigam, D.; Rani, V. Tea and human health: The dark shadows. Toxicol. Lett. 2013, 220, 82-87. [CrossRef] [PubMed]

139. Donaldson, K.; Stone, V.; Tran, C.L.; Kreyling, W.; Borm, P.J.A. Nanotoxicology. Occup. Environ. Med. 2004, 61, 727. [CrossRef] [PubMed]

140. Warheit, D.B.; Sayes, C.M.; Reed, K.L.; Swain, K.A. Health effects related to nanoparticle exposures: Environmental, health and safety considerations for assessing hazards and risks. Pharmacol. Ther. 2008, 120, 35-42. [CrossRef]

141. Homayouni, H.; Kavoosi, G.; Nassiri, S.M. Physicochemical, antioxidant and antibacterial properties of dispersion made from tapioca and gelatinized tapioca starch incorporated with carvacrol. LWT Food Sci. Technol. 2017, 77, 503-509. [CrossRef]

142. Cui, H.; Yuan, L.; Li, W.; Lin, L. Antioxidant property of SiO2-eugenol liposome loaded nanofibrous membranes on beef. Food Packag. Shelf Life 2017, 11, 49-57. [CrossRef]

143. Liu, F.; Avena-Bustillos, R.J.; Chiou, B.-S.; Li, Y.; Ma, Y.; Williams, T.G.; Wood, D.F.; McHugh, T.H.; Zhong, F. Controlled-release of tea polyphenol from gelatin films incorporated with different ratios of free/nanoencapsulated tea polyphenols into fatty food simulants. Food Hydrocoll. 2017, 62, $212-221$. [CrossRef]

144. Estevez-Areco, S.; Guz, L.; Candal, R.; Goyanes, S. Release kinetics of rosemary (Rosmarinus officinalis) polyphenols from polyvinyl alcohol (PVA) electrospun nanofibers in several food simulants. Food Packag. Shelf Life 2018, 18, 42-50. [CrossRef] 
145. Carlson, C.; Hussain, S.M.; Schrand, A.M.; Braydich-Stolle, L.K.; Hess, K.L.; Jones, R.L.; Schlager, J.J. Unique cellular interaction of silver nanoparticles: Size-dependent generation of reactive oxygen species. J. Phys. Chem. B 2008, 112, 13608-13619. [CrossRef] [PubMed]

146. Smolkova, B.; El Yamani, N.; Collins, A.R.; Gutleb, A.C.; Dusinska, M. Nanoparticles in food. Epigenetic changes induced by nanomaterials and possible impact on health. Food Chem. Toxicol. Int. J. Publ. Br. Ind. Biol. Res. Assoc. 2015, 77, 64-73. [CrossRef] [PubMed]

147. Bhabra, G.; Sood, A.; Fisher, B.; Cartwright, L.; Saunders, M.; Evans, W.H.; Surprenant, A.; Lopez-Castejon, G.; Mann, S.; Davis, S.A.; et al. Nanoparticles can cause DNA damage across a cellular barrier. Nat. Nanotechnol. 2009, 4, 876-883. [CrossRef] [PubMed]

148. Pan, Y.; Neuss, S.; Leifert, A.; Fischler, M.; Wen, F.; Simon, U.; Schmid, G.; Brandau, W.; Jahnen-Dechent, W. Size-dependent cytotoxicity of gold nanoparticles. Small (Weinh. Der Bergstr. Ger.) 2007, 3, 1941-1949. [CrossRef] [PubMed]

149. Kim, T.H.; Kim, M.; Park, H.S.; Shin, U.S.; Gong, M.S.; Kim, H.W. Size-dependent cellular toxicity of silver nanoparticles. J. Biomed. Mater. Res. Part A 2012, 100, 1033-1043. [CrossRef]

150. Manickam, V.; Velusamy, R.K.; Lochana, R.; Amiti, A.; Rajendran, B.; Tamizhselvi, R. Applications and genotoxicity of nanomaterials in the food industry. Environ. Chem. Lett. 2017, 15, 399-412. [CrossRef]

151. Amenta, V.; Aschberger, K.; Arena, M.; Bouwmeester, H.; Botelho Moniz, F.; Brandhoff, P.; Gottardo, S.; Marvin, H.J.P.; Mech, A.; Quiros Pesudo, L.; et al. Regulatory aspects of nanotechnology in the agri/feed/food sector in EU and non-EU countries. Regul. Toxicol. Pharmacol. 2015, 73, 463-476. [CrossRef]

152. Cushen, M.; Kerry, J.; Morris, M.; Cruz-Romero, M.; Cummins, E. Nanotechnologies in the food industry-Recent developments, risks and regulation. Trends Food Sci. Technol. 2012, 24, 30-46. [CrossRef]

153. EFSA Scientific Committee; Hardy, A.B.D.; Halldorsson, T.; Jeger, M.J.; Knutsen, H.K.; More, S.; Naegeli, H.; Noteborn, H.; Ockleford, C.; Ricci, A.; et al. Guidance on risk assessment of the application of nanoscience and nanotechnologies in the food and feed chain: Part 1, human and animal health. EFSA J. 2018, 16, 5327-5395.

154. The European Regulation on Registration, Evaluation and Authorisation and Restriction of Chemicals (REACH). Commission recommendation of 18 October 2011 on the definition of nanomaterial (2011/696/EU). Off. J. Eur. Union 2011, L275/238-L275/240.

155. Kessler, R. Engineered nanoparticles in consumer products: Understanding a new ingredient. Environ. Health Perspect. 2011, 119, a120-a125. [CrossRef] [PubMed]

156. Decker, E.A. Phenolics: Prooxidants or Antioxidants? Nutr. Rev. 1997, 55, 396-398. [CrossRef] [PubMed]

157. EFSA Panel on Food Additives and Nutrient Sources added to Food (ANS); Younes, M.; Aggett, P.; Aguilar, F.; Crebelli, R.; Dusemund, B.; Filipič, M.; Frutos, M.J.; Galtier, P.; Gott, D.; et al. Scientific opinion on the safety of green tea catechins. EFSA J. 2018, 16, e05239. [CrossRef]

158. Borowska, S.; Brzóska, M.M.; Tomczyk, M. Complexation of bioelements and toxic metals by polyphenolic compounds-Implications for health. Curr. Drug Targets 2018, 19, 1612-1638. [CrossRef]

159. Martirosyan, A.; Grintzalis, K.; Polet, M.; Laloux, L.; Schneider, Y.-J. Tuning the inflammatory response to silver nanoparticles via quercetin in Caco-2 (co-)cultures as model of the human intestinal mucosa. Toxicol. Lett. 2016, 253, 36-45. [CrossRef]

(C) 2019 by the authors. Licensee MDPI, Basel, Switzerland. This article is an open access article distributed under the terms and conditions of the Creative Commons Attribution (CC BY) license (http://creativecommons.org/licenses/by/4.0/). 